\title{
CIRCLE OF AUNTIES \\ FOSTERING CO-CONSPIRATORSHIP WITH FAMILIES OF MMIWGT2S \\ IN THE RESISTANCE OF SETTLER COLONIAL VIOLENCE
}

by Laura Heidenheim

Bachelor of Arts, Ryerson University, 2017

\author{
A project paper \\ presented to Ryerson University \& York University \\ in partial fulfillment of the \\ requirements for the degree of \\ Master of Arts \\ in the program of \\ Communication and Culture
}

Toronto, Ontario, Canada, 2019

(C) Laura Heidenheim, 2019 


\section{AUTHOR'S DECLARATION FOR ELECTRONIC SUBMISSION OF A MRP}

I hereby declare that I am the sole author of this MRP. This is a true copy of the thesis, including any required final revisions, as accepted by my examiners.

I authorize Ryerson University to lend this thesis to other institutions or individuals for the purpose of scholarly research.

I further authorize Ryerson University to reproduce this thesis by photocopying or by other means, in total or in part, at the request of other institutions or individuals for the purpose of scholarly research. I understand that my thesis may be made electronically available to the public. 


\title{
CIRCLE OF AUNTIES \\ FOSTERING CO-CONSPIRATORSHIP WITH FAMILIES OF MMIWGT2S \\ IN THE RESISTANCE OF SETTLER COLONIAL VIOLENCE
}

\author{
Laura Heidenheim \\ Master of Arts 2019 \\ Communication and Culture \\ Ryerson University \& York University
}

\begin{abstract}
This paper details the co-research creation project "Circle of Aunties" outlining our processes, contributions and key learnings. The paper will begin by locating the author and the project's approach and move to detailing our process - exploring the Circle of Aunties toolkit and the coresearch creation process. The paper will then outline the contribution this project makes to educational tools that create awareness around racialized gender-based violence in Canada and its relationship to existing literature regarding co-conspirator work. Co-conspirator/accomplice work are "alternative framework(s)" to allyship which call for "white scholars and activists to act as accomplices, working in solidarity with people of color within social justice and anti-racist movements" (Powell Kelly, 42). This paper explores our process of co-conspiratorship, bringing our project into conversation with contemporary anti-colonial efforts and calling for the prefacing of relationship in anti-colonial projects.
\end{abstract}

Key Words: Co-conspiratorship, Accomplice, MMIWGT2S, Racialized Gendered Violence, Settler Colonial Violence, Settler Colonialism, Curriculum 


\section{ACKNOWLEDGEMENTS}

This project would not be possible without the guidance and support of my committee, Dr. Lila Pine, Dr. Cyndy Baskin and Dr. Ruth Koleszar-Green - I am so honoured to have had you by my side throughout this process. Wela'lioq, Nya:weh, Meegwetch!

I want to thank the families of Missing and Murdered Indigenous Womxn and Girls that I have worked with to date. Your strength and resiliency have taught me so much and it has been an honour to come to know the stories of your loved ones.

To my sister Emma - thank you for always listening. Thank you for never hesitating to lend a helping hand and for being my rock. To my dear friend Sarah - thank you for your unwavering support, patience and laughter. To my friends - thank you for keeping me grounded and pulling me through whatever challenges come my way.

To my parents, I am so fortunate to have you. Your sacrifices and selflessness have meant that I have never doubted my path in life. I love you. 


\section{DEDICATION}

"We are all visitors on this planet, we all have to go when the time comes, but can remain as spirits forever. Memories can be relived in the mind and maybe we'll meet again"

- Sonya Nadine Mae Cywink

This work is dedicated to my co-creators, co-writers and beloved aunties; Maggie Cywink, Joyce Carpenter, Shauna Kechego-Nichols, Linda John and Vanessa Brousseau. It is dedicated to their loved ones Sonya Nadine Mae Cywink, Patricia Carpenter, Heleyna Rivera and Pamela Holopainen. 
TABLE OF CONTENTS

$\begin{array}{lr}\text { INTRODUCTION } & 1 \\ \text { TERMINOLOGY } & 2 \\ \text { COMMUNITY RELEVANCE: RESISTING SETTLER COLONIAL STRUCTURAL } & 8 \\ \text { GENOCIDE \& CENTRING MMIWGT2S FAMILIES } & 11 \\ \text { PROJECT APPROACH \& METHODOLOGY FRAMEWORK } & 12 \\ \text { INDIGENOUS FEMINIST THEORY } & 13 \\ \text { EMPLOYING INDIGENOUS METHODOLOGY } & 15 \\ \text { EMPLOYING ARTS BASED METHODS \& CO-CREATION METHODS } & 16 \\ \text { CHAPTER 1 PROCESS: THE RESEARCH CREATION PROCESS } & 18 \\ \text { CREATING TOGETHER: DETAILING OUR PROCESS } & 19 \\ \text { GATHERING \#1: DEFINING OUR GUIDING BUNDLES \& RIPPLE EFFECT } & 23 \\ \text { DESIGNING THE TOOLKIT STRUCTURE } & 25 \\ \text { SYNTHESIS \& LITERATURE REVIEW } & 28 \\ \text { GATHERING \#2: BUILDING OUR TOOLKIT } & 40 \\ \text { CHALLENGES OF COMPLETING ANTI-COLONIAL WORK WITHIN THE ACADEMY } \\ \text { CHAPTER 2: CONTRIBUTIONS TO PROFESSIONAL PRACTICES } & 29 \\ \text { CHAPTER } 3 \text { : MOVING BEYOND PERFORMATIVE ALLYSHIP TO ACTIVE CO- } & 33 \\ \text { CONSPIRATORSHIP WITH MMIWGT2S FAMILIES } & 36 \\ \text { TRUTH, RESPONSIBILITY AND ACTION } & 36 \\ \text { EMPOYING COMENION SETTLER COLONIAL RHETORIC } & 51\end{array}$ 


\section{LIST OF FIGURES}

Figure 1: Journal Entry, Diagram Mapping Our Co-Creation Process....................................... 18

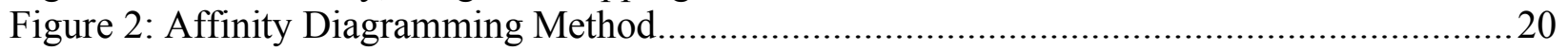

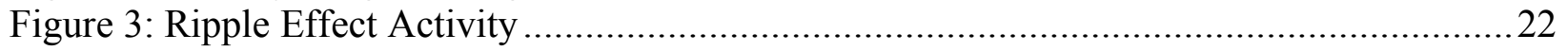

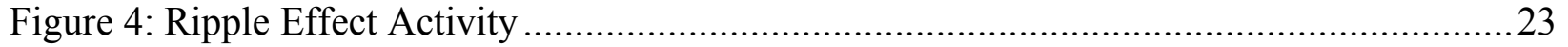

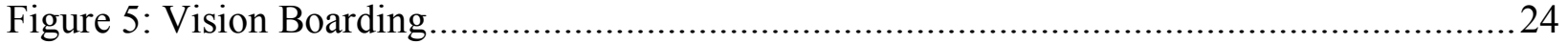




\section{INTRODUCTION}

Utilizing autoethnographic layered accounts, this paper will detail the co-research creation project "Circle of Aunties" outlining our processes, contributions and key learnings. The goal of this paper is twofold, to both explore the project created and its contribution to the field of educational tools as well as detailing our co-research creation process. We will employ the work of Indigenous feminist scholars and critical race scholars while utilizing self-observation and self-reflection materials in order to answer our question, 'CAN we (a guest/settler and a group of MMIWGT2S families), create a transformative project by working together and centring the lived experience of the families?'. The paper will begin by locating the author and the project's approach and move to detailing our process - exploring the Circle of Aunties toolkit as well as our creation process. The paper will then outline the contribution this project makes to educational tools that create awareness around racialized gender-based violence in Canada and its relationship to existing literature regarding co-conspirator work. Co-conspirator/accomplice work are "alternative framework(s)" to allyship which call for "white scholars and activists to act as accomplices, working in solidarity with people of color within social justice and anti-racist movements" (Powell Kelly 42). This paper will work to detail our process of co-conspiratorship, bringing our project into conversation with contemporary anti-colonial efforts.

Within scholarship around Indigenous methodologies, relationship is consistently and constantly stressed. As Margaret Kovach expresses, the relationship and receptivity between the researcher and participants is a "natural part of the research "methodology"”(28). Anishnaabek Métis scholar Lynn F. Lavallée speaks to the temporal commitment of these relationships, extending "well beyond the final report, dissertation, peer-reviewed article submission, or conference presentation" the relationship is "a lifelong relationship and commitment" (Lavallée 24). It is therefore vital that I begin by speaking to my relationship to this work - interrogating my privilege as a white womxn and acknowledging the people who have informed my knowledge. I also must address where I am speaking from, locating my knowledge and my identity. Within, "Putting Ourselves Forward: Location In Aboriginal Research"Anishinaabe scholar Kathy Absolon and Cree scholar Cam Willett emphasize locating oneself as an ethical research methodology, explaining that as an "anti-oppressive methodology, location brings 
ownership and responsibility to the forefront", noting researchers owning "who or what they represent" also reveal "what they do not represent"(110 emphasis added). It is the work of these scholars which has informed my decision to utilize autoethnography in my writing - as to flip the gaze onto myself and bring my own positionality into the conversation. This practice also helps to challenge scientific objectivity and the omniscient voice of knowledge, or the "distant voice of the objective observer/writer" which is recognized by feminist and postmodern thinkers as " a mechanism of power which ensures the domination of certain accounts"'(Kimpson 75) .

\section{TERMINOLOGY}

Throughout this paper I will be using the acronym MMIWGT2S, which stands for Missing and Murdered Indigenous Womxn, Girls, Trans and Two Spirit People. I am specifically referencing MMIWGT2S in "Canada". Instead of "women" or "woman", I employ "womxn" throughout this paper. The predecessor of "womxn" is "womyn" which originated in the 1970s and is associated with the "often white, cisgender sector of the feminist movement" and "often tied to the vein of feminism that does not view trans women as women" (Lampen). Rejecting and resisting transphobia, the use of "womxn" honours those who identify "outside of the male/female gender binary, use several labels" and identify with labels including, "gender variant, gender non-binary, genderqueer, gender diverse, intersex, transgender, and non-binary folx". Incorporating the " $\mathrm{x}$ " is a way to resist binary conceptions of gender and "bring in more identities to the conversations, such as womxn, latinx, and alumx to name a few" (Robertson 47). When I mention 'families' and 'MMIWGT2S families', I am referring to the five family members who are co-authors and co-creators of this project; Maggie Cywink, Joyce Carpenter, Vanessa Brousseau, Shauna Kechego-Nichols and Linda John. I speak in the plural throughout this paper as the families and I have co-created this knowledge together. Looking to work by Indigenous scholars such as Dr. Julie Tomiak, I place "Canada" in scare quotes to question its legitimacy as a settler colonial state which has violently dispossessed Indigenous land from Indigenous Peoples (Tomiak 2016). Honouring and drawing from the work of Mohawk scholar Dr. Ruth Koleszar-Green, I employ "settler-guest" throughout this paper when discussing nonIndigenous peoples. Koleszar-Green explains a settler to be someone who may know "that they are on stolen land" and who may know "whose 'traditional territory' they are on, and they might 
wish to be a good ally, but usually a settler's intentions stop there". In comparison, Guests are non-Indigenous people who understand "through a reflexive process that as a Guest they have responsibilities to learn about rematriation of the land", they learn the history of the land they live on and are "active and respectful individual who recognizes their privilege and uses that privilege in a way that does not centre themself but centres the community" (174). I use "settlerguest" as to employ this distinction between passive settlers and guests who are "in relationship to the Land in a way that supports stewardship and not ownership" and are "in relationship with Onkwehonwe communities and who respects reciprocal engagement” (Koleszar-Green 175). I also use "settler-guest" to signal that it is possible to move between these identities - to move from settler to guest or guest to settler. I am a "guest" when working with MMIWGT2S Families as we are able to engage in meaningful and productive co-conspirator work together. In other spaces, such as work around the repatriation of Indigenous land, I am a settler as I have not engaged in productive co-conspirator work and I am a benefactor of stolen Indigenous land.

\section{LOCATING THE AUTHOR}

As Indigenous Peoples increasingly take up the politics of refusal, the settler too must demonstrate a willingness to be refused. Settler privilege is the basis for injustice and oppression of Indigenous peoples, the privilege of the settler is predicated on the unfreedom of the colonized. The labor of settlers should be to imagine alternative ways to be in relation with Indigenous peoples (Flowers 34).

In her impassioned piece, "Refusal to forgive: Indigenous womxn's love and rage" Rachel Flowers, a hwulmuhw slheni from Leey'qsun Nation interrogates the settler "ally" and calls for solidarity which involves the decentring of the privileged and re-imagining ways of being productively in resistance (35). It is with great respect of her work that I seek to embody this call to action, while also following her prompt of imagining alternative ways of being in relation. As a womxn who is a survivor of sexual violence, I refuse to centre whiteness in my conversations of sexual violence and my advocacy work around resisting gender-based violence. Instead, I centre my responsibility as a settler-guest, a survivor and the granddaughter of Jewish ancestors who were murdered in the Holocaust to work towards co-conspirator work and interrogate racialized gendered violence. I refuse to accept the violent settler colonial systems 
which oppress Indigenous womxn, womxn of colour, trans womxn and gender diverse folks and I refuse to accept the institutional oppressions which make services such as the police, victim services and healthcare inaccessible and dangerous for the 2SQTBIPOC community - while they remain accessible for me. As a womxn whose ancestors were German Jewish refugees and murder victims who lost their lives in the Auschwitz concentration camp, I am moved to challenge the ongoing structural genocide of the settler colonial state in my work and seek to work as a co-conspirator with families of MMIWGT2S. I am moved to reimagine ways in which to resist structural genocide, honouring my personal connection to genocide while centring loved ones of MMIWGT2S.

Although Flowers calls for re-imagining ways of being in relation, she is clear that one must be critical of this work and understand that "anticolonial resistance does not require the disappearance of difference, nor should co-resistance foreclose alterity and oblige co-existence", as "sites of domination and resistance are distinct, they are also connected; it is often the case that the site of co-resistance is where domination is put into practice and violence is forced into the mind and onto the body of the colonized" (37). Co-conspiratorship does not assume coexistence, as coexisting within the settler colonial state means participating in a system which operates on stolen land and denies Indigenous Peoples the right to self-governance. Instead, coconspiratorship means being in resistance of the settler colonial state and understanding one's privilege as a settler-guest:

Maybe some Indigenous peoples don't want or need settler co-resistance because we don't trust them. Many Indigenous peoples are not willing to forgive settler violence, so how can we trust and move forward in co-resistance without first being able to relinquish our resentment? This places the onus on Indigenous peoples to facilitate moving forward with settler society for a shared future of co-existence on our lands and in our lives. Though Indigenous peoples rebel against the permanence of the settler colonial reality, maybe some are not ready to sever themselves from the colonial relationship yet. For many Indigenous peoples the settler never ceases to be the enemy; the settler cultivates righteous anger within the colonized (Flowers 37 ). 
I approach Flower's call to action with careful scrutiny of my own privilege. I acknowledge and honour that, while I work in collaboration with a group of Indigenous womxn, there are many Indigenous folx who may refuse my efforts. I also honour that this re-imagining must be done in collaboration and must be informed by the vast amount of work written by Indigenous scholars and activists who have defined how to approach co-conspiratorship in a productive and antioppressive way.

I am also critical of the act of positioning myself and referring to myself as a settlerguest on Indigenous land. I wish to place myself within this text as to call my positionality into conversation and analyze our process in completing a co-research design project. Being critical of my positionality and calling my whiteness into conversation does not remove me from being a benefactor of the settler colonial state, nor does it erase my role in upholding the settler colonial state. In "Decolonization is not a Metaphor", Eve Tuck and Wayne Yang explore "settler moves to innocence", where the settler population seeks to relieve "feelings of guilt or responsibility without giving up land or power or privilege, without having to change much at all" (Tuck and Yang 10). Tuck and Yang discuss academia as a site for moves to innocence, where one only focuses on "decolonizing the mind, or the cultivation of critical consciousness, as if it were the sole activity of decolonization; to allow conscientization to stand in for the more uncomfortable task of relinquishing stolen land" (19). Until my efforts as a settler-guest are actively involved in the relinquishing of Indigenous land in "Canada", my work falls short of being decolonial work. In identifying as a settler-guest I do not not wish to depoliticize myself or move my identity towards innocence, as Flowers notes, “when Indigenous peoples deploy 'settler' it identifies the enemy, whereas, when deployed by settlers it is often depoliticized and neutralized rather than counter-performative in its function"(38). I instead acknowledge my privilege and the responsibilities I have because of my identity.

My ancestors are, to the best of my knowledge, of European decent. On my father's side, my ancestors are German Jewish refugees who fled to Turtle Island/North America in the 1940s, escaping the Nazi regime. Most of my family who stayed in Europe, including my greatgrandparents, died in the Auschwitz concentration camp. My father's parents settled in London Ontario, the traditional territory of the Anishinabek, Onkwehonwe and Delaware peoples. I was raised in London, coming to Dish with One Spoon territory to pursue my university degree in 
2014. ${ }^{1}$ I was totally ignorant and complacent in contributing to settler colonialism until I began working with the Cywinks - a family from Whitefish River First Nation who lost their sister Sonya Nadine Mae Cywink to violence in 1994. At the time I was completing my undergraduate degree in media production at Ryerson University, taking a documentary film class. I had been moved by a recent MacLean's interactive article entitled "It Could Have Been Me". The article showed the stories of thirteen Indigenous womxn, bravely sharing stories of "terrible violence and formidable resilience — stories that, as one survivor hopes, will serve as 'a pay-it-forward of women sharing their pain and triumph"' (Macdonald 2015). I began searching online to see if there might be someone we could connect with about MMIWGT2S when I found Maggie's name. She is a grass-roots organizer, the Special Advisor to the Ministry of the Attorney General's Indigenous Justice Unit and a family member working to honour her sister. Maggie was eager to work with our documentary team to tell a story which was strength based. She introduced us to her brother Alex Cywink and together we created a documentary about their sister which celebrated the story of her life - not her death. It was in this relationship and this work that I began to invest a majority of my time and work in the MMIWGT2S community. Maggie introduced me to Joyce Carpenter (from Alderville First Nation), the mother of Patricia Carpenter who was killed in Tkaronto in 1992. It was with these two families that we began to create our exhibit, "Shades of Our Sisters". For the past four years, I have been learning from MMIWGT2S families and looking to their advocacy work and grassroots initiatives. My knowledge of this community comes from working with the families who have come to be a part of the exhibit, which now includes eight different families from Ontario. It also comes from my time working with a group of 21 families from Wabaseemong First Nation. Travelling with Spirit to Spirit, a grass-roots Indigenous organization which runs trauma informed healing gatherings for MMIWGT2S families, I spent a week in Kenora Ontario getting to know the Wabaseemong families; working with them to create commemorative images of their loved ones and assisting the organizers. I have continued to work with these families by supporting their community mobilization efforts, designing posters for their February 14th memorial walk. My work continues in various other forms, ranging from creating missing persons posters for

\footnotetext{
${ }^{1}$ Toronto and Ryerson University are in the "Dish With One Spoon Territory." The Dish With One Spoon is a treaty between the Anishinaabe, Mississaugas and Haudenosaunee that bound them to share the territory and protect the land. Subsequent Indigenous Nations and peoples, Europeans and all newcomers, have been invited into this treaty in the spirit of peace, friendship and respect (Ryerson School of Journalism).
} 
families or working to support families meeting with the OPP to assisting MMIWGT2S coalitions across the country with grant applications.

Looking to Absolon and Willett, I want to be clear about what I do not and cannot represent. I am not a representative of MMIWGT2S families, nor do I speak on behalf of families. We collaborate in our work together and any knowledge I have comes from their patience, love and guidance. It is also important to note that the families I work with are mainly Anishinabek and Onkwehonwe, meaning the teachings I have received only reflect the cultures of these specific communities. Furthermore, there are hundreds of MMIWGT2S families who I have never met and I haven't done anything to support their work. This leads to my final point, which is that I do not self-identify as an ally. Allison Hargreaves, an associate Professor at the University of British Columbia, reflects that as a white scholar the act of self-identifying as an ally can be "declarative or wholesale" especially when used to "name a self-appointed identity rather than a relational practice" (ix). Allyship is something which must be earned and it can only be given by the individuals with whom you have worked, demonstrating a "resolute commitment to transforming colonial relationships, while at the same time recognizing this work as socially and politically contingent - as responsive to the shifting circumstances of strategy, necessity, location and trust" (Hargraves ix). As a white womxn, I do not face settler colonial violence or experience intergenerational trauma. Allyship is a lifelong, unwavering commitment which must be earned with time and unwavering commitment. I therefore self-identify as someone who works towards centring those with lived experience and de-centring myself striving to embody authentic co-conspiratorship. I honour with deep respect when individuals $I$ have worked with call me an "ally", although in regards to the womxn I work with we generally use friendship to describe our relationship. I am careful to correct those I have not worked with, especially settlers-guests, as the only individuals who can determine my effectiveness are those with whom I have an ongoing relationship. I must also be clear about the benefits of this work for myself personally, as it has supported me in earning my masters degree. 


\section{COMMUNITY RELEVANCE: RESISTING SETTLER COLONIAL STRUCTURAL GENOCIDE \& CENTRING MMIWGT2S FAMILIES}

Verna Kirkness, a Cree scholar, and Ray Barnhardt have outlined ““4 'R's'”as a framework for conducting research/work in an Indigenous context calling for respect (for protocol and Indigenous knowledges), relevance (to community needs, experiences and to include the community in your design process), reciprocity (ensuring both the researcher and community benefit from the project) and responsibility (active empowerment for the community involved through engagement and participation) (Cauchie 6-7). Similarly, Anishnaabek Métis scholar Lynn F. Lavallée discusses that, like community-based research, within an Indigenous research framework research must be of importance and relevance to the community with the intent of creating social change. Lavallée also notes that while levels of participation may range within community-based projects, research involving Indigenous peoples should centre community in shaping "the research question, design, methods, analysis, interpretation, and dissemination"(24).

Coming from their desire to educate the next generation and resist gendered violence in honour of their loved ones, this project was conceived by the MMIWGT2S. Its relevance lies in a history of calculated, state-driven structural genocide. Together we are resisting and calling out Canada's crisis of four thousand Indigenous womxn, Girls, Transgender and Two Spirit People (MMIWGT2S)2; something which has been denied, obscured and largely ignored by the nation (Harvard et al.1). Indigenous womxn and girls represent only 4.3 percent of the total female population, yet they account for 16 percent of all female homicide victims in Canada (Global News 2014). This disproportionate and devastating rate of violence is not an anomaly but is state-driven and is the foundation of settler colonialism.

\footnotetext{
${ }^{2}$ Since the publication of the Royal Canadian Mounted Police's Missing and Murdered Indigenous Women: a National Operational Overview report, Native Women's Association of Canada (NWAC) and the Federal government have speculated, based on evidence collected from the families of Missing and Murdered Indigenous Women, that there are $4000+$ cases in need of further attention and understanding (Ontario Native Women's Association 2017).
} 
Australian anthropologist and ethnographer Patrick Wolfe is well known within postcolonial studies for his work around defining settler colonialism. Wolfe asserts that settler colonialism differs from colonialism in its inherent need to totally erase Indigenous peoples from the land which it invades, even erasing its own history of conquership in order to legitimize its ownership of land; simply put settler colonialism "destroys to replace" and is a "structure not an event"(388). Wolfe explains that unlike enslaved peoples whose "reproduction augmented their owners' wealth", Indigenous people stood in the way of the settler making progress and thus they had to be eliminated as the increase of their population was "counterproductive" (388). Wolfe calls this the logic of elimination. In recognizing Wolfe's logic of elimination one can understand that violence against Indigenous womxn has been deliberate, state driven and integral to the settler colonial state. There are two main mechanisms of control which the "Circle of Aunties" toolkit seeks to disrupt in its intervention within settler colonial school systems subjugated knowledge and structural genocide. Both subjugated knowledge and structural genocide are systemic tools used by the settler colonial state to counter truth and enable the violent attempted erasure of Indigenous Peoples. Structural genocide ensures the continuation of the state's attempted erasure of Indigenous Peoples by transforming and adapting acts of violence. Subjugated knowledge renders the truth of this genocide as illegitimate in the eyes of the settler population by publically disqualifying any claims which hold the state responsible or tell a counter-narrative. Therefore with these two mechanisms working together, the state has designed a system in which it can continue acts of genocide while performing innocence and disqualifying claims of its violence. The "Circle of Aunties" toolkit aims to enable youth to recognize structural genocide in all of its forms and understand the truth of settler colonial violence in "Canada".

Just as settler colonialism must be understood as a process and not one singular event, its actions must also be recognized as such. For this reason, Wolfe asserts that genocide within a settler colonial state must be called 'structural genocide' and understood not as one event but as a continued process of elimination. Wolfe explains that when invasion is a "structure rather than an event, its history does not stop". This means one must trace the state's continuous and transforming project of erasure as the "logic that initially informed frontier killing transmutes into different modalities, discourses and institutional formations as it undergirds the historical development and complexification of settler society" (Wolfe 402). Within the context of 
"Canada", understanding the state's actions as structural genocide means recognizing it has had to adapt from overt acts of violence to more subtle forms of erasure. In regards to violence against Indigenous womxn specifically, this has meant fostering apathy and ensuring that discussions of gendered violence do not include settler colonial violence. A predominant form of erasure is news rhetoric which dehumanizes the deaths of MMIWGT2S and fosters apathy amongst the settler colonial state. Pamela Palmater, a Mi'kmaq lawyer, professor and activist discusses that within the Canadian media womxn are presented as "good or bad and worthy of saving or not, based on deeply embedded racial constructs" often resulting in "victim-blaming discourse around Indigenous womxn and their "high-risk" lifestyles while ignoring the unequal socio-economic context from which they come" (Palmater 270). In this way, settler colonial governmentality ensures that the erasure of Indigenous womxn is normalized in the eyes of nonIndigenous citizens and upholds the project of structural genocide. The Canadian media's coverage of Missing and Murdered Indigenous womxn "signals to the public that crimes against Indigenous Women do not matter" (Palmater 270). As a tool of the state, structural genocide is able to adapt its actions.

The power of subjugated knowledge lies in its ability to suffocate voices attempting to hold the state accountable for its acts of settler colonial violence. Foucault explains subjugated knowledge to be both "historical contents that have been buried or masked" and "series of knowledges that have been disqualified" (Foucault 7-8). Violence against Indigenous womxn and the continuous, structural genocide by the Canadian state have been rendered subjugated knowledge as they are largely erased and, when brought to the forefront, denied as truth. A significant example of this came in 2006 when Prime Minister Stephen Harper cut all funding for "Sisters in Spirit". Created by Amnesty International and the Native Womxn's Association of Canada (NWAC), "Sisters in Spirit" was completing vital research which demonstrated the root causes of violence against Indigenous womxn. The research and work of this group resulted in a database of 582 documented MMIWG and hard evidence that these deaths were the product of a violent settler colonial system and not simply a phenomenon. Just as the work of "Sisters in Spirit" began to garner a large amount of media attention, Harper's government came to power and funding was cut. Not only did cutting the funding of this program work to silence these truths but it sent a powerful message to non-Indigenous citizens that this knowledge was not worth funding and was not legitimate. Activists continued their work to centre knowledge of 
settler colonial violence and push for a national inquiry. Nevertheless, in 2014 Harper made a statement which, yet again, denied legitimacy to MMIWGT2S saying an inquiry was not " on our radar, to be honest'"'(Simpson 2). By making this comment Harper was not only erasing violence against Indigenous womxn from the public's attention but was publicly disqualifying it as truth which was deserving of investigation. More recently, the coverage of a failing national inquiry only works to legitimize the previous government's claims that the inquiry was unnecessary. The "problematic" inquiry has meant that both the production of knowledge and the legitimacy of knowledge have been put at risk.

In an exercise during our first Circle of Aunties gathering, we wrote letters to the students and teachers who will one day use our toolkit. One family member eloquently wrote, "Dear teacher, thank you for taking the time to teach children what domestic violence is and how it is affecting our Indigenous womxn. My sister is one of the many missing and murdered, knowing that the loss of her may help someone provides some relief that it was for something". The Circle of Aunties Toolkit seeks to resist subjugated knowledge by providing youth with an educational experience which shapes their knowledge of settler colonialism and supports youth in recognizing their responsibility in resisting structural genocide. Taking an anti-oppressive, action-based approach the toolkit fosters a learning environment which honours MMIWGT2S while resisting apathy and complacency. The relevance of this project for our group lies in its potential to centre the voices of MMIWGT2S families, allowing their lived experience to call the next generation into action. This project comes in an important moment for MMIWGT2S families as, in the wake of the National Inquiry into Missing and Murdered Indigenous womxn and Girls (and in anticipation of the release of the final report this coming June 2019), it is vital that families feel empowered to create the solutions they wish to see in our country.

\section{PROJECT APPROACH \& METHODOLOGY FRAMEWORK}

Within a transformative and an anti-oppressive methodological framework, Circle of Aunties utilized Indigenous Feminist theory and Indigenous methodologies. Our co-research creation process employed co-creation methods, arts-based methods and Indigenous research methods. Within "Emerging from the Margins: Indigenous Methodologies" Kovach highlights specific questions one must ask when approaching research which involves Indigenous communities. The researcher must consider whether or not the research is manipulative or 
helpful, if the methodology is respectful to culture and community, and who is driving the research and for what purpose. For non-Indigenous scholars such as myself, Kovach emphasizes that a challenging and central question is "Am I creating space or taking space?" (Kovach 52). It is for this reason that we worked within an anti-oppressive framework as it allows for our work to be rooted in action and the wants/needs of MMIWGT2S family members. As explained by Potts and Brown within "Becoming an Anti-Oppressive Researcher", anti-oppressive researchers "set out to construct emancipatory and liberatory knowledge that can be acted on, by, and in the interests of the marginalized and oppressed"(Brown 20). The framework compliments Indigenous methodology in its emphasis on reciprocity and relevance, enabling the project to exist completely for the benefit of the community being "part of something larger, not an end in itself" and creating an "ongoing community-building enterprise" where it is the relationships and actions which are prioritized (Brown 37).

Circle of Aunties started by centring the families and their vision for their advocacy work. I approached a few of the families I worked with on Shades of Our Sisters and explained I would be doing my masters degree. I asked the families how and if I could be of use to them within the two-year program, emphasizing the project option for the course. The response was clear, that we must create something together which teaches the next generation about violence prevention - neglecting to teach youth would be a failure to actually work towards ending violence. It was with this focus that the project began to formulate. We began by identifying their goals for the project - working to outline the utility of the toolkit and explore how it can enact change structurally as well as for each youth who experiences the toolkit. Within an antioppressive framework we prioritized action while taking the time to build relationship not only as a working group but with other communities, which I will expand on later. Our focus was also on the sustainability of the project as something which can continue to grow and involve other MMIWGT2S families, not only the womxn participating within our working group.

\section{INDIGENOUS FEMINIST THEORY}

Looking to Indigenous feminist theorists such as Cheryl Suzack and Audra Simpson I connect gendered violence to settler colonial violence. Indigenous feminist theory embraces intersectionality to analyse patriarchal and colonial systems as well as investigating how gender identity "represents the source of widespread incidences of violence against Indigenous womxn 
through cultural practices that amplify womxn's social, political, and cultural disempowerment" (Suzack 261). Utilizing an Indigenous feminist lens allows me to include content which educates youth around the connections between the violence which Indigenous womxn face and the systemic, racist institutions which continue to foster this violence and have at their core a "legacy of state-sponsored violence in the form of colonial displacement and assimilation meant to evict Indigenous peoples from the land and to naturalize settlement” (Hargreave 90).

Indigenous feminist theory has empowered our work to focus on decolonization and Indigenous sovereignty while biasing Indigenous knowledge and the values of Indigenous womxn over patriarchal, Western knowledges and values.

\section{EMPLOYING INDIGENOUS METHODOLOGY}

In Research Is Ceremony, Indigenous Research Methods Shawn Wilson, an Opaskwayak Cree scholar, writes that our paradigms as researchers influence the tools we chose to use, emphasizing that "we can never really remove the tools from their underlying beliefs" (13). As a white scholar engaging in a co-research creation project it is important that I resist the legacy of harmful and exploitative research practices while also being cautious not to appropriate Indigenous research methods. I need to chose methods which are rooted in anti-oppressive values while also working with the families to find methods which honour their paradigms as Indigenous womxn with lived experience. I will admit that at first, within our thesis preparation class, when I was told to write a proposal and outline my methodology the process felt odd and rather forced. These womxn had already shown me how to approach this kind of work. We had already spent time working together as collaborators and found a methodology which worked for us - built on relationship, trust and respect. Outlining our research methods felt cold, clinical and detached from our relationships. At the same time, the process of the Research Ethics Board at Ryerson University made me question if our work was valid and if we could complete this project within the institution. I felt uncomfortable with articulating this work as 'research' and resisted the dichotomy of detached researcher and research subject. Turning to authors like Wilson started to alleviate this anxiety, as I began to understand that my methodology could be centred around our trusted relationships. Indigenous methodologies allowed me to name our process and embrace it as legitimate. Lynn Lavallée's article "Practical Application of an Indigenous Research Framework and Two Qualitative Indigenous Research Methods: Sharing 
Circles and Anishnaabe Symbol-Based Reflection" has heavily influenced my thinking around Indigenous research methods and articulating process. Lavallée asserts that Indigenous research is "not objective, nor does it see itself as unbiased", and those "conducting the research are necessarily connected to the individuals being researched, and all concerned are connected to all other living things" (23). Similarly, Anishinaabekwe scholar Kathy Absolon and Cree scholar Cam Willett address Indigenous methodologies within, "Putting Ourselves Forward: Location In Aboriginal Research". Willett and Absolon explain that if you want to do ethical research, you must centre relationship: "We're saying if you want to do ethical research that accurately represents who it is for - then you have to be positioned and connected to the work - and argue that in fact it is unethical to do Indigenous research without having an emotional connection" (104).

As I began to articulate our process as a valid research process I remember a sense of relief. It struck me that of course our process was legitimate and of course it was rooted within the paradigms of Indigenous methodologies - because it had been created by the families. I wrote a journal entry in October of 2018 after reading Kovach's writing on Indigenous Methodologies; "Our method started three years ago (...) it has been cups of tea, hugs, tears - creating together and spending time together". This realization brought a sense of renewed purpose to this paper, which I didn't recognize as being an important part of my process at first. I was resistant to spending time on an academic paper when I wanted to focus my time on creating anti-oppressive work which was tangible and productive. I soon realized, however, that detailing our process was anti-oppressive work because it was centring the process of the families - honouring their knowledge production as legitimate and critical, while resisting oppressive structural barriers such as the Research Ethics Board.

We used mixed methods within the research creation process, choosing methods which honoured our varying positionalities and would support our knowledge production as a group. Having participated in sharing circles with this group of womxn before - it felt appropriate to employ the sharing circle and story as a method as it was something we were all familiar with as a way in which to share knowledge. Kovach explains that within Indigenous epistemologies there are two forms of stories; one form of story holds mythical elements and the other consists of "personal narratives of place, happenings and experiences" (Kovach 138).The sharing circles allowed for families to share their personal narratives and utilize their lived experiences to 
inform the design of the toolkit. Using story as method also allowed space for "honouring the talk"(Kovach 144) by allowing those within the circle to speak for as long as they need and taking an approach which allows those participating to control the process. This was especially important in speaking with families of Missing and Murdered Indigenous Womxn and Girls as the storytelling process is rooted in healing and is deeply personal. Within this method, families are able to share what they need to share when they need to share it, providing a forum to "relate their stories in a holistic fashion" that is not interrupted or "fragmented by a structured interview process" (Kovach 144). I will expand on the specifics of how we used this method within the process section of this paper.

\section{EMPLOYING ARTS BASED METHODS \& CO-CREATION METHODS}

In order to ensure this project is anti-oppressive and rooted in the values and wants of the MMIWGT2S families we utilize co-creation and arts-based methods within the research-creation process. Greenhalgh et al. define co-creation as "the collaborative generation of knowledge by academics working alongside stakeholders from other sectors" (393). Successful co-creation projects are able to move "beyond the ivory towers" to deliver significant societal impact via dynamic, locally adaptive community-academic partnerships" with a focus on "improving human experience, and careful attention to governance and process" (392). We also used artbased methods as a way in which to express the values of the group. Lavallée explains Anishnaabe symbol-based reflection to be an adaptation of photovoice. Where photovoice

enables "people to record and reflect their community's strengths and concerns" and "to promote critical dialogue and knowledge about personal and community issues through large and small group discussions of photographs", Anishnaabe symbol-based reflection allows participants to use other kinds of symbols (e.g., paintings, drawings, sculptures, crafts, songs, teachings, and stories). Together we created visual art, word art and creative writing. We used co-creation methods such as storyboarding, affinity diagramming and role-play to define our guiding values for the toolkit and think through every aspect of the toolkit experience. I will expand on these methods within the process section and provide visual examples. 


\section{CHAPTER 1 PROCESS: THE RESEARCH CREATION PROCESS}

In Practice-Led Research, Research-Led Practice in the Creative Arts Hazel Smith and Roger T. Dean explore the dichotomy of process and goal orientation in the research creation process. Smith and Dean note that when the research is process-driven, it has "no particular starting point in mind and no preconceived end" allowing for "emergence, that is the generation of ideas which were unforeseen at the beginning of the project”. Projects can also be goalorientated where there is a "clear idea of an ultimate objective or target outcome". The authors stress that these two models of research creation are "by no means entirely separate from each other and often interact"(23), which is where the Circle of Aunties Toolkit falls. November 11th, 2019, I wrote a journal article after speaking with my supervisor Dr. Lila Pine. My research question had originally been 'How can we (a guest/settler and a group of MMIWGT2S families), work to centre their knowledge and lived experience with the purpose of creating a transformative project?'. I was struggling with this question as well as how to organize all of the moving pieces involved within the project. This was the first time I began to critically interrogate my process and how it operated as a co-research creation project:

I sat down yesterday and began to critically look again at my process. It seems that I need to articulate that it is twofold: experimenting with method while also creating something tangible. This is a co-research creation project which is process driven. We are creating something while also testing and reflecting on the process of creation. Today Lila helped me to improve my research question, suggesting that the question is not "How can" but simply "can".....CAN we (a guest/settler and a group of MMIWGT2S families), work to centre their knowledge and lived experience, and can we create a transformative project? We are approaching this question with an anti-oppressive and transformative framework, meaning that the interests and needs of MMIWGT2S families are at the core. This is especially important, in this moment, as in the wake of the national inquiry families are feeling they have been taken advantage of and largely ignored. This question comes at a moment where it is vital to explore how families can be empowered to make the changes which they want to see for the next generation, in honour of their loved ones. I am trying to answer "can" because I recognize the wisdom of this group of womxn - but also know that they are extremely busy and all give so much energy and time to others. Two of these 
families are raising the children of their daughters who were murdered - they are grandmothers, caring for their family.

I am placing myself in this question because I want to see if we can work together in a way which is empowering and enables womxn who have limited time and energy, to create something incredible. Can I de-centre myself and exist as a stewart of their knowledge? Can we come together in a space and share, design, create something which honours their loved ones and teaches the next generation? Can this project support the healing of these families? Can we work within a process which allows the families to clearly articulate their vision in our time together, and gives me clear instructions and direction for when we are apart and I am reviewing other toolkits/starting to piece things together? Can our iterative process ensure that the families are able to constantly shape the project and protect their vision? Can I use the privilege I possess as a white, cisgender womxn within an educational institution to work to hold space, listen and centre the knowledge of this group of MMIWG families? Can a colonial institution, like Ryerson, accommodate this kind of work? Can the REB and program admin recognize this as legitimate knowledge production? (Heidenheim 8-10)

By coming to understand that our work would be process driven and orientated towards our goal of producing the toolkit, I could make sense of the duality of our project. While we would be creating something tangible we would also be testing and creating our methodology, playing in what Flowers calls the "unknown and 'in-between' spaces of resistance" (35) and finding alternative ways to be in relation. Our research question asks us to interrogate the notion of reconciliation, looking first and foremost to truth and the act of refusing complacency to the settler colonial state. Research creation supports the very nature of co-creation work, which inevitably takes unexpected turns and can even see the goal changing/adapting throughout the process. Research creation also supports our anti-oppressive framework by allowing the work to bend and shift - keeping pace with the values and needs of the MMIWGT2S community. As I 
will detail further in the following section, this flexibility was imperative as the project took turns and transformed in ways we could not have predicted.

\section{CREATING TOGETHER: DETAILING OUR PROCESS}

As we began our working process I was cautious to explore how I could exist as a steward of the knowledge creation process. I looked to Lavallée's reflection on stewardship

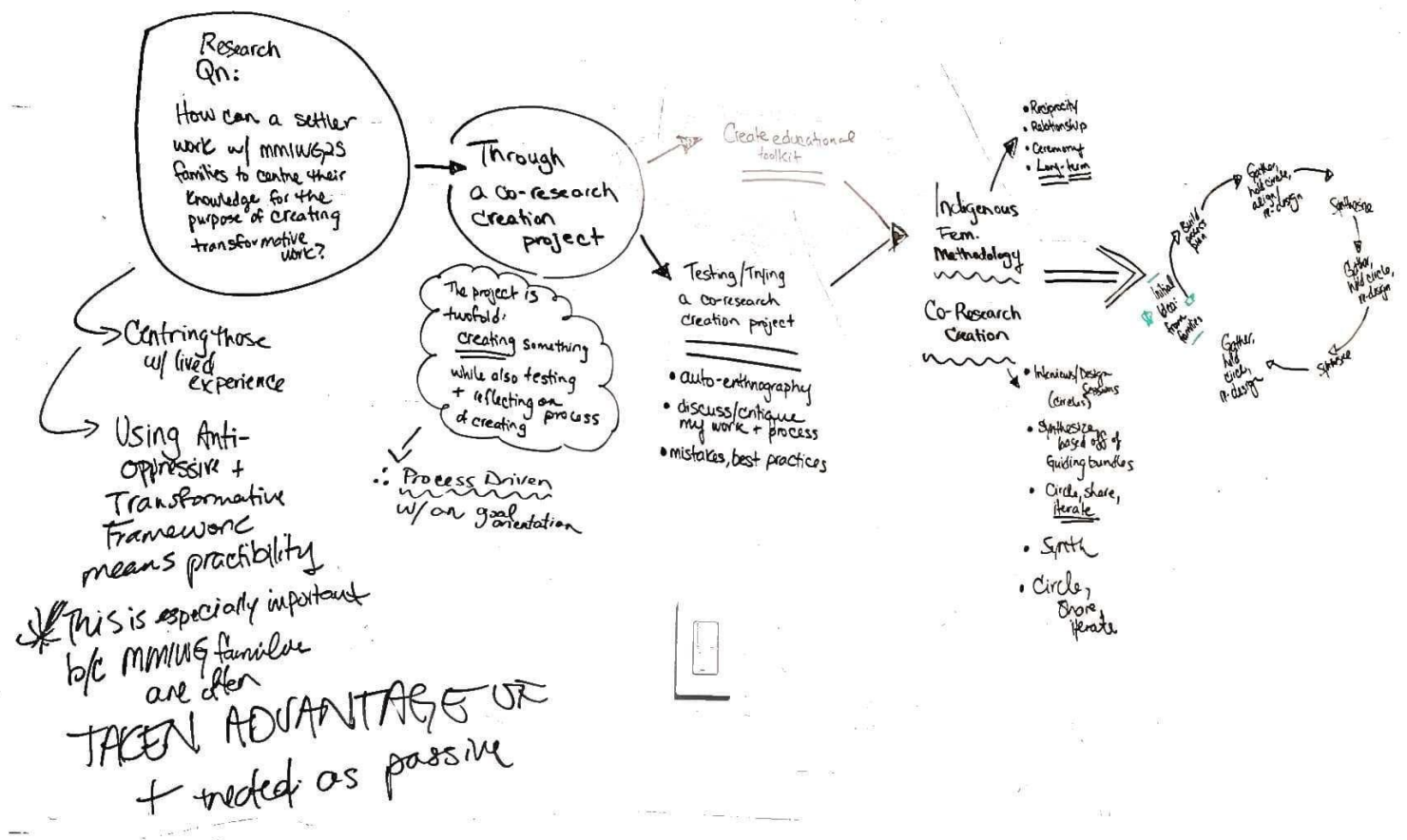

Figure 1: Journal Entry, Diagram Mapping Our Co-Creation Process

within community projects to define this role: "I confirmed my role as steward of the data and the fact that the community owned the project. The community was very open and trusting, so much so that they would often turn my questions back and ask me what I thought, effectively making me a participant and themselves stewards. This switching and overlap of roles is part of the fluidity of the process" (Lavallée 26). Wilson discusses ownership within research, explaining that "if knowledge is formed within a relationship, it can't be owned" as reality is a "set of relationships" and therefore no one person can claim ownership over it (114). Wilson gives the example of gaining knowledge as being married to someone, "you don’t own your spouse or 
children but you do share a special relationship" one which you are accountable to. Therefore, cultural appropriation occurs when knowledge is used "out of the special relationships that went into forming it" (114). For myself personally, this means that any knowledge the families have shared with me must be used within the context of our work together and with their involvement. It was with this perspective that I approached the design of our first session together. I knew the process had to be shared and that our previous relationships and the knowledge we had already produced together should be centred.

This knowledge informed the labour I needed to embark on as well as helping to call my privilege into conversation. The family members are all extremely busy womxn; they are community leaders, most are raising children, working full time and balancing extremely full lives. My privilege places me within a master's program where I am able to work full time on our project. I have no children to care for, my income is steady and I do not face the intense emotional labour which this work evokes for these womxn. Our time spent on Shades of Our Sisters informed my knowledge of working together and being in collaboration. These knowledges steered the design of our first gathering; dictating how we planned together, created together and what labour I needed to take on. The approach was that I would prepare as much as possible and provide a place for the group to start (with the intention of tearing things apart, reimagining and rewriting once we began working together). Our process, as it has been with Shades Of Our Sisters, is collaborative. Families are always guiding and shaping while I work to follow their vision and push the progress of the project along; fostering authentic collaboration while also meeting the ambitious goals of the group. This has meant finding a balance between using my privilege and time to make significant progress on the project (in order to meet the goals of the families) and taking time to gather, iterate and reshape.

\section{GATHERING \#1: DEFINING OUR GUIDING BUNDLES \& RIPPLE EFFECT}

Our first gathering took place November 1st - 3rd 2018 at Ryerson University. During a conference call in October we discussed the purpose of this first meeting. The families wanted it to be about "their own strengths and gathering as a group", balancing the three days with "time to visit and to work" (Heidenheim 1). The goals of our first day together would be to determine 
who we are as a group, what was important to us, what the goals of the toolkit were and to identify what questions we have. On the second day our work would turn towards defining the structure of the toolkit, beginning to design its sections and think through the experience. We began our sharing with a talking stick ceremony, something which Maggie Cywink has shared knowledge with me about and invited me to participate in prior to our gathering. In "The Learning Circle as a Research Method: The Trickster and Windigo in Research", Herb Nabigon, an Elder from Pic River First Nation, Rebecca Hagey, Schulyer Webster and Rober MacKay explain the difference between talking stick ceremony and learning circles. Within talking stick ceremony, nothing leaves the circle and each person's "subjective reality" belongs to their time in the circle, as does "mutual learning, joking and healing" (115). This differs from learning

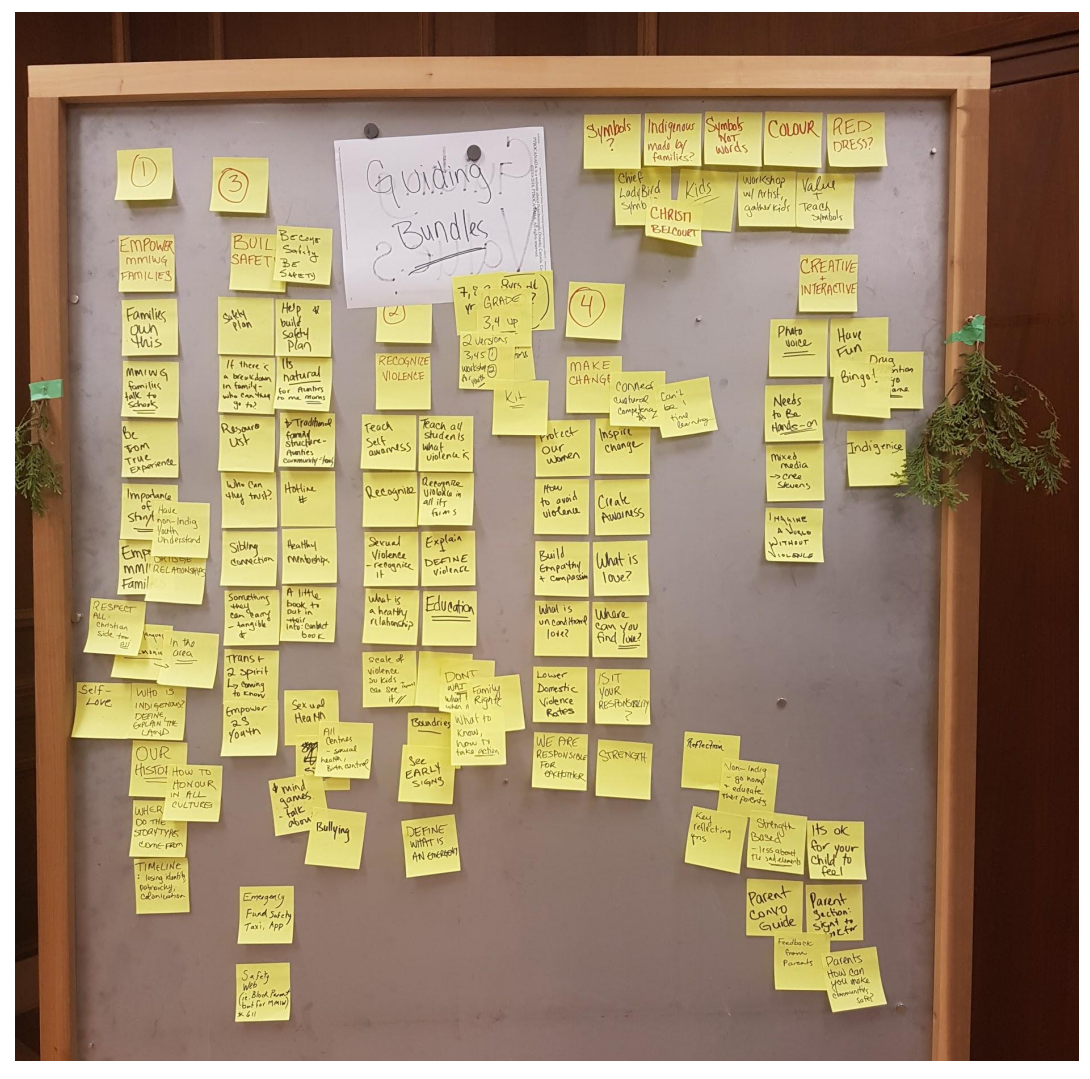

Figure 2: Affinity Diagramming Method circles where information is permitted to be shared, with the consent of the group, for knowledge production (116). We have used both of these approaches to sharing before and therefore these methods worked well for our group. Starting with a talking stick ceremony enabled us to connect on a deep level and prepare for the emotional labour we would be embarking on together; speaking from the heart about the work and what it means to each of us. Our learning circles and co-creation process began by aligning on my position as steward and our working relationship. The following is an excerpt from the gathering guide and my first words to the group as we began our work: 
My job and my commitment to you, is to be a steward of these ideas. I don't own them but I will take care of them by taking everything away and organizing it, doing research, and beginning to put things together. When we meet again, you will take the work I have done and tear it apart, build on it, and push it even farther. Part of my promise to you, is that this is a lifelong commitment. What we have done in April, when I show this to the professors, won't be perfect and we will still have work to do. I will continue to do that work until this is successful and you are all happy.

Within our learning circle we began with ideation questions as to build our vision for the project and identify any gaps we may have in our knowledge. We asked and discussed: "Why are we all participating in this project?", "What do we hope will come from it?", "What do we want this toolkit to do, to achieve?", “What questions do we have?", and "What are we curious about?". As the group shared, we also employed the affinity diagramming where, writing one thought per post-it note, each thought that is shared goes up on a wall for the group to see. Once we had worked through all of our questions we started to group the sticky-notes as to create design principles for the group to follow. This method is an inductive tool, meaning "the work is done from the bottom up, by clustering specific, small details into groups, which then give rise to the general and overarching themes" (Martin et al. 12). The families renamed these principles 'Guiding Bundles' and identified four main groups: Empower MMIWGT2S Families, Recognize Violence, Be Safety and Be Change. Each of these Guiding Bundles would help to keep the group focused and define the main goals/values of the toolkit. The focus of 'Empower Families' is to centre the voices of MMIWGT2S families, not only our immediate group but eventually the wider MMIWGT2S community. This means ensuring the toolkit shares the authentic stories of MMIWGT2S and gives families the option to control their own narratives. 'Empower Families' also calls for the toolkit to interrogate settler colonialism and the genealogy of settler colonial violence in "Canada". Our second Guiding Bundle, 'Recognize Violence', was a strong theme which was very important to the group as womxn with lived experience. Families expressed that the toolkit should teach youth about consent, personal safety, boundaries and healthy 
relationships. They also wanted youth to understand what domestic violence is, how to recognize early warning signs of abuse and to understand different forms of violence and abuse.

'Be Safety' focuses on the toolkit providing resources for youth to keep themselves safe and as well as being safety for others. Families want to see a balance of tools for youth to consider their own safety as well as the knowledge of how to recognize when to speak up and help someone else. The final Guiding Bundle, 'Be Change' challenges the toolkit to inspire empathy, compassion, responsibility and action in the youth who experience it. This also calls for the toolkit to be strength-based and to support youth in engaging in owning their role in ending violence.

With our Guiding Bundles created, we moved to thinking through the impact we want the toolkit to have. Looking to Frog Design's Community Action Toolkit, we turned to the 'Ripple Effect' activity which helps to consider the "impact you want your group to have - from improving people's lives in your community to changing your country or the world" (Fabricant

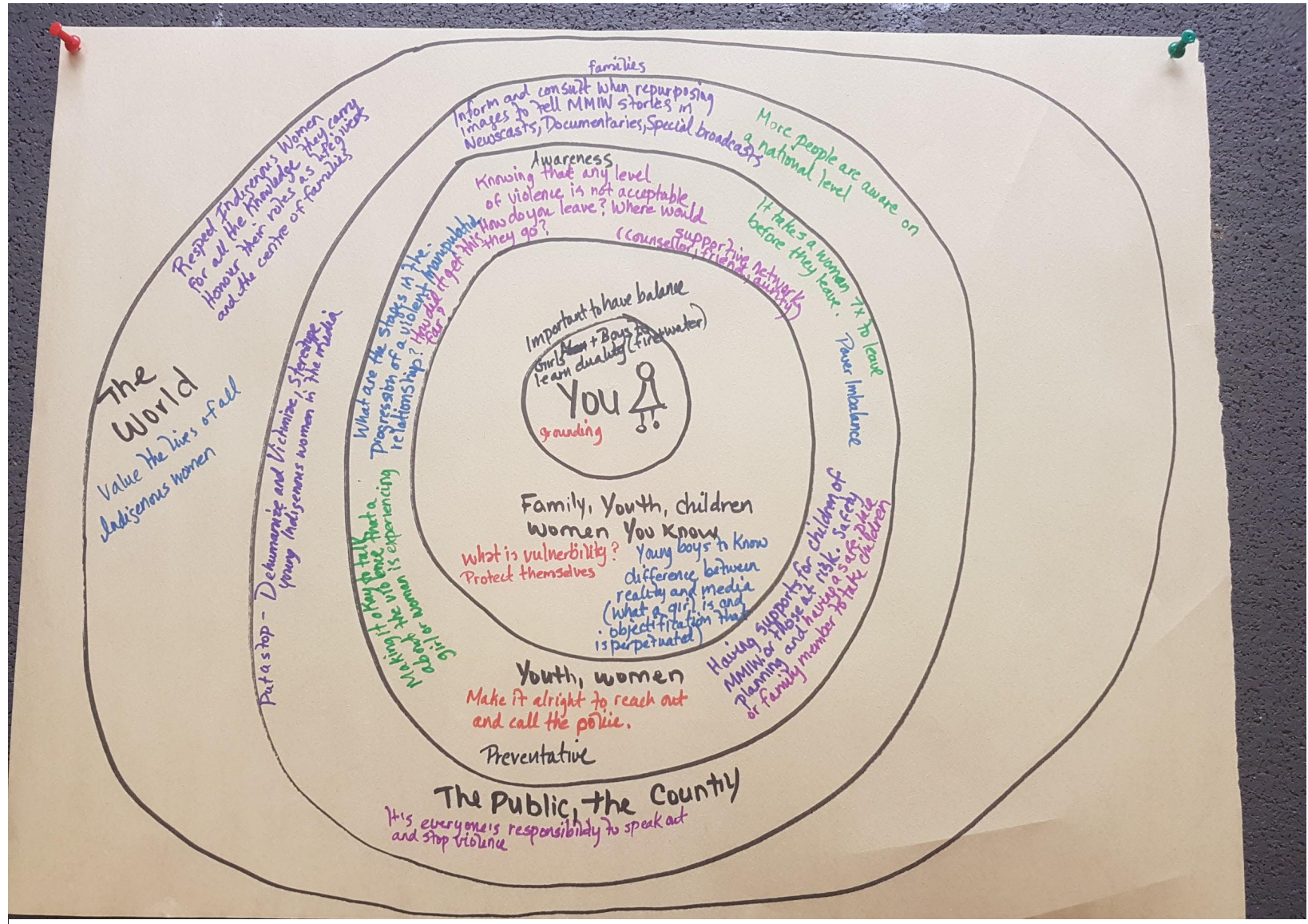

Figure 3: Ripple Effect Activity 
et al 8). Starting with ourselves we moved our thinking out to our families and people in our lives, to womxn and girls, the entire country and finally to the world. At each level we considered what we wanted the toolkit to do for the people within that category, asking ourselves what it would look like if the toolkit was successful. This helped us to think through our Guiding Bundles and consider critically what our vision for the toolkit is. It became clear that our goals are layered, ranging from extremely personal goals to structural and systemic goals. On a personal level families want the toolkit to be "healing" and build a "deeper connection with families". Systematically there are hopes that the toolkit could change the health care system, improve transitional housing systems for womxn and "build bridges between Indigenous and non-Indigenous peoples".

\section{DESIGNING THE TOOLKIT STRUCTURE}

Once we had defined our goals and Guiding Bundles, our group moved towards designing the structure of the toolkit. Based on our youth engagement work within Shades of Our

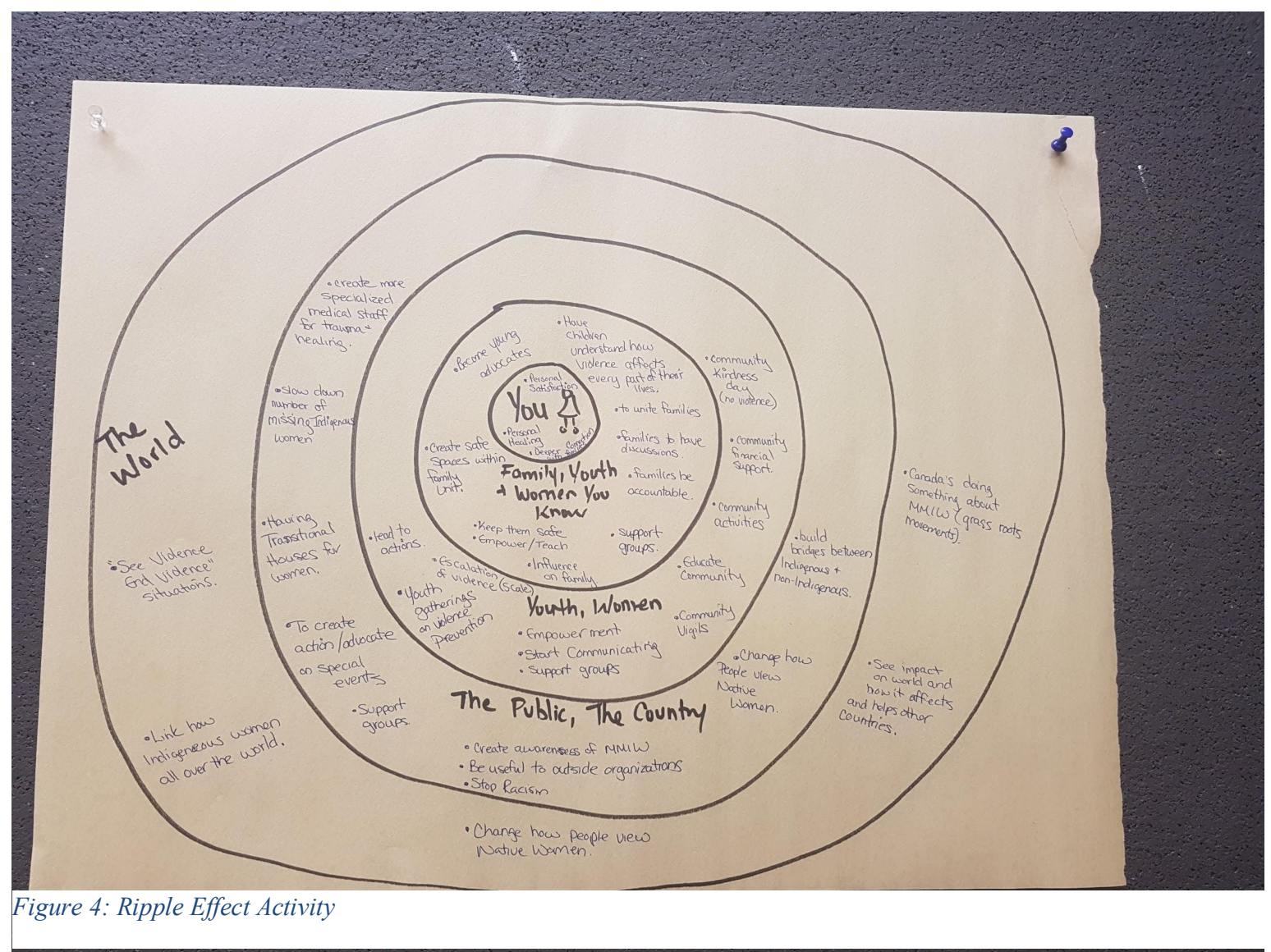


Sisters, I drafted a rough outline for what this toolkit could look like. As a group we thought through the structure and the families began re-writing and re-imagining. We used role-play to think through the unique needs of each person who will experience the toolkit. This involved thinking through the entire process of the toolkit and considering the settler-guest teachers who will be teaching this material and the training they will need or how different youth with experience the toolkit depending on their positionality. We also created vision boards, looking through other toolkits and violence prevention curriculum to gain inspiration and discuss what we think is effective and what we want to avoid. We began sketching our ideal toolkit by cutting out what inspired us and pasting it on our vision boards. We finished our first gathering by

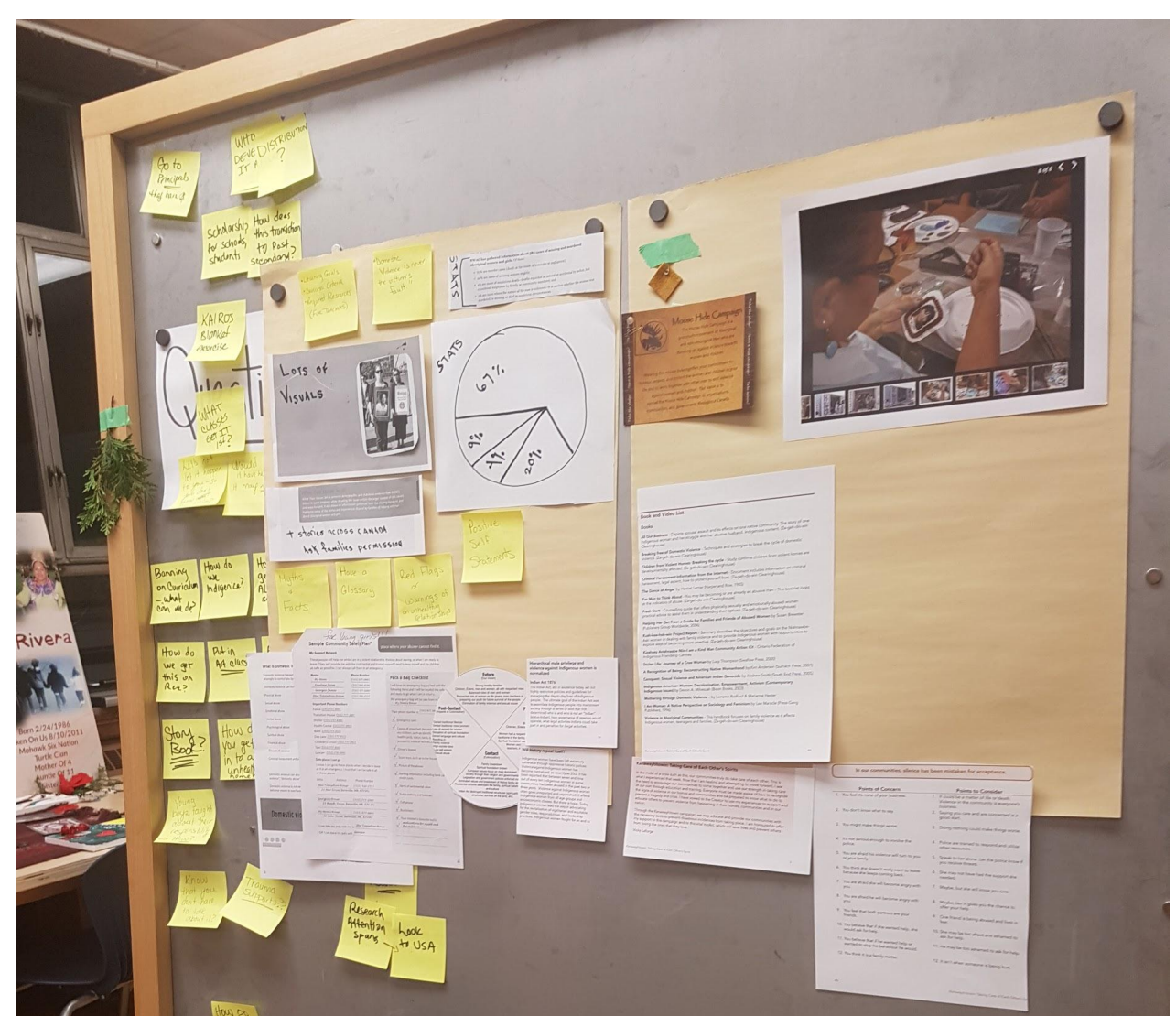

Figure 5: Vision Boarding writing letters to the future students and teachers who would use our toolkit, centring the voices of the families and honouring the extremely emotional and personal nature of this work.

By the end of our first gathering we were able to articulate that the

toolkit would have four major sections: 1. Curriculum: focusing on defining violence and providing youth tools for staying safe; 2. Stories: empowering families to share their stories and explaining settler colonial violence; 3 . Who Will You Honour?; a prompt for youth to create something in honour of those who have lost their lives to violence; 4. Community Gathering: an opportunity for youth to share what they have learned and engage with community. We also 
agreed that we would create two versions of the toolkit, one which is curriculum based for grades 4 and 5 and another which is more flexible and could be used by older youth (14 and up).

\section{SYNTHESIS \& LITERATURE REVIEW}

A major surprise which came from our first research session together was the shift from my original assumptions about what the project would be about and who it was for. At the end of our second day together I reflected on this shift:

What has shocked me, maybe the most - is the families don't want it to be all about MMIWG. They want it to be about all violence prevention. They want to center all. They want to protect all youth and prevent all violence (...) to create a toolkit which is FROM AN INDIGENOUS PERSPECTIVE, but for ALL. When I first envisioned meeting as a group, I wasn't sure what the final product would be - but I thought we were building a toolkit which taught MMIWG as the core - and violence prevention would be something that was not the main point but would be a part of the learning. But the families brilliantly flipped everything. They don't want MMIWG to be the centre, they want violence prevention at the centre, for ALL youth - but for it to be taught from an MMIWG perspective, with lived experience. What blew me away about this, was that they are decentring themselves - to centre youth, all youth. I am so focused on centring them always and their stories, loved ones, all MMIWG - that I never envisioned them stepping back and saying - this isn't just about us. They even spoke about taking the "I" out of MMIWG (...) their ontology and epistemology isn't the subject, it's the method. The SUBJECT is violence prevention, but it is being taught from the perspective of an MMIWGT2S family member. (Heidenheim 3)

Based on our work within Shades of Our Sisters, I assumed our toolkit would only be about violence against Indigenous Womxn, Girls, Trans and Two Spirit people. Similarly to how the exhibit creates a space for youth to think critically about MMIWGT2S and consider their role in violence prevention, I assumed the goal of the toolkit would be to inspire both settler-guest youth and Indigenous youth to resist settler colonial violence. I had drafted a toolkit outline which saw 
youth learning about settler colonialism and the history of MMIWGT2S, followed by stories from families and a gift making activity where youth created something in honour of MMIWGT2S. As our Guiding Bundles began to form it became clear that the families were suggesting something much larger - a toolkit which addressed all violence and had the goal of keeping all youth safe. I had been so focused on centring the families and centring MMIWGT2S that I never expected them to decentre themselves. One of the toolkit sections I had drafted called "Gifts", was meant specifically for youth to create something to honour MMIWGT2S families, a piece of art perhaps or a letter. The families re-wrote this section to be "Who Will You Honour?", making the point that if anyone in the class had lost a loved one to violence, there should be space for their life to be honoured. The scope of the project became much larger than I had anticipated and was now not only about MMIWGT2S but supporting all youth in understanding the importance of violence prevention in their lives.

This shift challenged me to expand my literature review and research not only MMIWGT2S toolkits/curriculum but toolkits which teach consent, healthy relationships and violence awareness for all youth. Using our Guiding Bundles, I reviewed eleven toolkits regarding violence/abuse and fifteen teaching resources for MMIWGT2S, choosing only "Canadian" content. I reviewed and analyzed each toolkit and curriculum by considering if and how each toolkit satisfies our four Guiding Bundles. In this way, I could use the values we had set as a lens through which to sort materials and determine what would be useful to us and what did not align with our project. Within this process I was able to find major gaps in current MMIWGT2S toolkits, which I will expand on later, as well as what makes our project unique. The first unique characteristic of our project is the grass-roots nature of our working group whereas the other toolkits I found come primarily from agencies. For this reason, we have the potential to share personal stories and address loss in a meaningful and transformative way. Our toolkit is also unique as we have a strong call to action/mobilization component. Most of the toolkits I reviewed have rather weak calls to action, generally at the very end of the lesson and with little substance.

Another shift in the project came at this point, as I began to find that there were many strong toolkits which met a lot of our goals, specifically 'Recognize Violence' and 'Be Safety'. In particular, Drawing the Line on Sexual Violence by the Elementary Teachers' Federation of Ontario (ETFO), Walking In Her Moccasins by the Congress of Aboriginal Peoples and You Are 
Not Alone and/or Honouring womxn Project, by the Native womxn's Association of Canada. A month after our first meeting together I presented this information to the families and suggested that perhaps we use these toolkits in conjunction with our toolkit. I began to realize that this would set our process back as we would need to discuss these details in person, as a group however we wouldn't be meeting again until the new year. On January $8^{\text {th }} 2019$ I reflected on the challenges of our process and began to realize that our 'setbacks' were actually proof that our process was working:

In the interest of allowing the families to begin the project openly with as little of my influence as possible - our first meeting was "blue sky" thinking - suggest anything and everything, no matter the feasibility, and that will direct my labour. I didn't expect that they would want such an emphasis on teaching consent, sexual health, boundaries, etc. but I did think it was important to let the families direct where the project started to avoid me too heavily influencing topic/design/research. My hope was that this meeting would create a big "to-do" list and would create boundaries and a lens for me to do research work which is guided by THEIR vision. The result of this was when I went away and researched what they had suggested - it already existed. Perhaps this does prove the success of our process - as I was able to step back and have the families design/dictate direction. The result of this influenced what I went forward to research. Because I was being guided by their vision, I wasn't prepared/hadn't completed a literature review which could catch the fact that this work has been done before. Co-design processes are difficult as you truly do give up control. Traditionally I would have done this work before - I would have known everything that existed before we met, but because we are in a truly collaborative process - I didn't know what I would be researching until after our meeting together. I believe this catch 22 proves that our method is working - it is not a failure, rather, proof of our collaborative process. When we meet we can discuss this and it will ultimately be up to them if they want to follow my suggestion or go forward with the original plan before the literature review. Allowing method and project design to be in the hands of others means you have to adapt and be flexible - it means watching the needs and wants of a group carefully and having to honour that. (Heidenheim 14) 
While we had hoped to be writing the toolkit in February, our process forced us to slow down and instead focus on collaboration with other organizations and building a network of support. If we collaborated with these groups we could focus on the unique qualities of our work while supporting the work of others and fostering collaboration.

\section{GATHERING \#2: BUILDING OUR TOOLKIT}

The main goals of our second meeting were to align as a group, review the research I had completed and make key decisions about the design of the toolkit as to begin the writing process. Together we reviewed my findings from the literature review and discussed the possibility of combining our toolkit with Drawing the Line on Sexual Violence, Walking in Her Moccasins and You Are Not Alone and/or Honouring womxn Project. After reviewing each toolkit as a group, the families agreed that adding these toolkits to our own would be best, as to avoid "reinventing the wheel". Our toolkit will work in collaboration with these three, allowing educators to decide

which one is most appropriate based on their students. Drawing the Line is designed for a diverse group of students and has been written as to adhere to the Ontario curriculum, Walking in Her Moccasins is made specifically for Indigenous boys and young adults (although its creators at the Aboriginal People's Congress stress that it could be of benefit to any youth) and, You Are Not Alone as well as the Honouring Women Project serve as tools for Indigenous girls and young adults. In this way, experiencing the Circle of Aunties toolkit means starting with lessons in personal safety which are specific to the group of students and moves to action-based learning which comes authentically from loved ones of MMIWGT2S. Our second meeting together also saw us redefine our timeline for the project, aiming for a June 2020 Ontario launch and a June 2022 national launch. With these key decisions made we began drafting a rough sketch of the toolkit and are currently aiming to begin workshopping the curriculum with educators this summer. As our iterative process continues and we begin to invite more people into the cocreation process, it is the decisions made within these first two gatherings which will guide the project and keep centred the work of the loved ones of Missing and Murdered Indigenous Womxn, Girls, Trans and Two Spirit People. 


\section{CHALLENGES OF COMPLETING ANTI-COLONIAL WORK WITHIN THE ACADEMY}

Part of the focus of our research question was to reflect on the institution in which our project was hosted - the university. Completing this work within an educational institution was of benefit to me personally as I was able to work on our project whilst gaining my degree, allowing space for this work to be done with critical focus. I have had the honour and absolute privilege of working with my committee who are able to offer their invaluable guidance as part of their roles as academics within the institution. We have been able to gain financial support, access to space and free rentals of equipment. What has been challenging are certain protocols and institutional barriers which contradict our process, in particular the Research Ethics Board (REB). In reflecting on the process of the REB I have found that there are certain areas of the institution where anti-colonial work is met with resistance and ignorance. The process was emotionally and mentally draining, putting a significant strain on the progress of our project. Kovach explains, "As conservatism is recharging itself in the academy, it is an arduous (though not unfamiliar) struggle for intellectuals engaged in critical discourse to procure a slice of the epistemic pie. Carving space for emancipatory research in the academy, particularly for 'new' methodologies, like Indigenous research, is exhausting. Questioning established views about what counts as meaning, knowledge, and truth provokes defensiveness" (21). After a full board review with the Research Ethics Board I certainly felt this exhaustion, "My research question is can we do this work. We can, but the institution will not support it. The institution will put up roadblocks" (Heidenheim 15). My privilege as as white cisgender womxn has meant that I have faced little institutional oppression in my academic career. I am able to move through the institution without facing racial bias and access services without difficulty. As scholars Powell and Kelly explain, when engaged in co-conspirator work one must dismantle oppressive systems, which can lead to "cognitive dissonance and discomfort for many allies who benefit from these systems in ways they do not understand until that privilege and benefit is threatened" (59). The white privilege I have benefited from my entire life meant that I was not used to systems working against me. I was frustrated by the process and at the same time was forgetting my privilege - failing in the moment to be critical of my positionality. On January 29th, 2019 I reflected: 
The only reason I can do this work is because of the labour of Indigenous scholars who have put so much work into demanding/making space for Indigenous methodology and resisting western/eurocentricism. I was so frustrated by the REB's process that I think I lost sight of how fortunate I was to be able to go into the REB review and reference Dr. Eve Tuck and Dr. Kathy Absolon-King. I am SO FORTUNATE to be able to call upon the labour of these brave scholars who have been resisting oppressive systems their entire lives, not because they have chosen to but because they HAVE to - for survival (Heidenheim 15).

As I white cisgender womxn I have faced little oppression or significant barriers from the university. After six years of studying at Ryerson University, I am extremely privileged to be experiencing institutional barriers for the first time and to be writing about these barriers within an academic paper. In detailing my experience I hope to highlight the institution's oppressive practices and demonstrate the need for an anti-colonial research ethics process which honours Indigenous methodologies.

Our protocol was first submitted August 31st, 2018. After six rounds of review we received ethics approval January 25th, 2019. This included a full board review where I was interviewed by thirty board members, followed by two more rounds of review, (one of which included over fifty questions). To date my responses to the board totals over fifteen thousand words. An ongoing question which was repeated in each round of review was around my previous relationship with the families and their ability to consent to the project, expressing "concern that participants might have a sense of obligation to participate" due to their "previous (and potentially ongoing) relationship with you outside of this research project”. There was a clear lack of understanding around the importance of relationship when doing work which involves Indigenous communities. Kovach notes that research based on relationship is integral and a "practical necessity because access to the community is unlikely unless time is invested in relationship building", defining relationship as "sincere, authentic investment in the community; the ability to take time to visit with people from the community" (30). There is an especially heightened need for relationship within our work as the subject matter is deeply personal and emotional. I would have no right to approach these womxn without our previous relationships 
and built trust. I also would not be able to have an authentic relationship with the womxn if we had not worked together before and had an ongoing relationship. Our previous relationship was positioned as a conflict of interest instead of a legitimate and integral method. Instead of questioning the authenticity and depth of our relationship, which would have been beneficial to the project, our "potentially on-going relationship" was positioned as problematic.

The collaborative nature of our work was largely dismissed and the intelligence and agency of the families were constantly questioned. Reviewers asked, "Please comment on the expectation that families should only participate if they think the project will benefit them? How will they know the benefits?". This question is highly paternalistic and implies that these womxn would not instinctively know if a project in honour of their loved ones would be of benefit to them. It ignores and denies the collaborative nature of the work and it offends their agency as intelligent womxn who can identify work which is of value to their healing and honouring of their loved ones.

Another challenge came in justifying our consent process. Similarly to the questioning of our relationship, the board's call for signed consent forms denied the legitimacy of our trust and history as a group of collaborators. In “An Application of Two-Eyed Seeing: Indigenous Research Methods With Participatory Action Research” Anishinaabe-kwe Cindy Peltier reflects on the consent process, noting that it puts those with trusted relationships in an uncomfortable position and puts those relationships at risk: "As a researcher-in-relation, I will admit that the formalities of obtaining informed consent required by all Research Ethics Boards felt antithetical to the relationship-building I had accomplished" (7). Signing a contract would have insulted the trust and emotional bond which we as a group hold. I instead offered the woxmn tobacco and we spoke within our circle about my commitments to them as a steward of the work, opening up space and opportunity for discussion. Not only would the consent form have been counterproductive in regards to our relationship-building, but it would have introduced a historically oppressive practice and, as Wilson emphasizes, "we can never really remove the tools from their underlying beliefs" (13). Traditional western research and its practices evoke "images of ethnographers, missionaries, explorers, and social scientists voyeuristically noting their observations and labelling Indigenous peoples as hedonistic, barbaric and savage" (Absolon and Willett 114). In order to shift from these oppressive and paternalistic practices, it was vital 
that we follow processes which were natural and comfortable for our entire group and reject anything else.

During the Research Ethics Board full review, one reviewer remarked, "We have you fill out these boxes . . . but answers don't always fit". It struck me that the system was so incredibly rigid with no ability to adapt or effectively guide anti-oppressive work. I wonder, if the REB had spent five months building our capabilities as a co-researchers instead of questioning our capabilities what the potential for growth could have been. After the review I reflected on their process, "They worry about check boxes so they can answer to the Tri-council review - but where is the authentic concern for the people I work with? (...) It felt like we were crafting something for the benefit of the institution. After meeting with these 30 board members I, yet again, will have to answer more questions. None of which get to the core of Indigenous methods and none of which truly operate to serve these families" (Heidenheim 15). 


\section{CHAPTER 2: CONTRIBUTIONS TO PROFESSIONAL PRACTICES}

The Circle of Aunties Toolkit makes a unique contribution to both consent/violence awareness resources and settler colonial educational resources. I reviewed eleven consent/violence awareness resources (Drawing the Line on Sexual Violence, Walking in Her Moccasins, You Are Not Alone Facilitator Book, You Are Not Alone Guide Book, PEACE Project, Community Action Campaign to Prevent Women Abuse in the Indigenous Community, Am I Experiencing Abuse?, I Am A Kind Man, Workshop: The Hidden Face, It Starts With You It Stays With Him and Their Voices Will Guide $U s$ ) and ten MMIWGT2S educational resources (Why Are Missing And Murdered Indigenous Women Cases Being Ignored?, Canada's Missing and Murdered Indigenous Women, Canada Marches For Missing And Murdered Indigenous Women, What Their Stories Tell Us, Finding Dawn, Fact Sheet: Violence Against Aboriginal Women, Fact Sheet: Root Causes of Violence Against Aboriginal Women, Fact Sheet: Missing and Murdered Aboriginal Women and Girls and Community Resource Guide: What Can I Do to Help the Families of Missing and Murdered Aboriginal Women and Girls?). Our toolkit offers two unique contributions to these resources: it comes directly from MMIWGT2S families, authentically centring them in the creation of the toolkit, and it is focused primarily on action through story, art and community gathering. I will discuss specifically The Native Women's Association of Canada's Community Resource Guide: What Can I Do to Help the Families of Missing and Murdered Aboriginal Women and Girls? and The Congress of Aboriginal Peoples' Walking in Her Moccasins, as to highlight the pre-existing work which our work will complement and enhance.

Written by the Sisters In Spirit Initiative within the Native Women's Association of Canada (NWAC), Community Resource Guide: What Can I Do to Help the Families of Missing and Murdered Aboriginal Women and Girls? is an action-orientated handbook with the goal of equipping those interested in supporting families of MMIWGT2S. The toolkit aims to educate and empower those interested in advocacy work to hold community events, stating "Everyone can play a role. Be informed, get involved, and mobilize!" (NWAC 7). The toolkit begins with key information regarding settler colonialism and MMIWGT2S statistics, moving quickly to 
outlining options for taking action. Where Circle of Aunties stands apart from this toolkit, is our authentic and active centring of MMIWGT2S families. A blatant example of the exclusion of families comes in section 2b) "Toolkit: Navigating the Missing Persons Process". The introduction to this section states:

The very prospect of having a missing loved one is something we hope you and your family never have to experience. We can only imagine what parents, grandparents, other relatives and friends must feel when they realize someone close to them is missing. We have heard that this process can be very isolating and emotionally overwhelming, and we want you to know that NWAC and our Sisters In Spirit initiative are here for you.

Section 2 of the guide discusses specifically what to do when someone goes missing or has been murdered, detailing resources for families to access. This section would especially have been powerful if it came from families with lived experience and knowledge around accessing these services. Instead of the authors suggesting "we can only imagine" the experience, centring families in writing this section would have seen this section of the toolkit coming from experience and shared trauma, while also positioning families who feel able to take on this work (especially those who feel this work supports their healing process) as experts. Following our 'Guiding Bundles', Circle of Aunties empowers the loved ones of MMIWGT2S and centres their knowledge as to exist as an anti-oppressive tool.

Created by the Aboriginal People's Congress in collaboration with the White Ribbon Campaign, the Walking in Her Moccasins Bundle is a profound teaching resource. The bundle has four main sections, "Where we are", emphasizing shared healing, "Where we've been", exploring the history of settler colonialism, "What Exists and What Needs To Exist" promoting positive masculinity through traditional teachings, and, "Where are We Going", emphasizing healthy relationships and community building. The toolkit exists as a "resource to address violence against Indigenous women and girls so that strategies will create change", fusing lessons around settler colonialism and structural genocide with traditional teachings, “As Indigenous peoples, we have the sacred teachings and the answers to make change" (Aboriginal Peoples Congress). In "Where we've been", there is a section specifically about MMIWGT2S, “Teaching \#4: Missing And Murdered Indigenous Women And Girls". The section details talking points for the facilitator to introduce to the group, exploring the disproportionate rate of 
violence which Indigenous womxn face and holding space for anyone in the room to share if they have personally lost a loved one. While the section holds a significant amount of information, the 'call to action' component is underdeveloped. The toolkit sees youth watching the documentary, "Finding Dawn", (a film about Dawn Crey, an Indigenous woman who has been missing since December of 2000 from Vancouver's Downtown Eastside), and then splitting into groups to discuss "what actions communities and individuals may take, similar to the Memorial Walk featured in 'Finding Dawn"' (Aboriginal Peoples Congress). There is no space built within the toolkit for youth to carry out any of these actions - only to discuss them in small groups and present back to the larger group. This section fails to create space and time for youth to develop and run their proposed action, going only as far as ideation. The Circle of Aunties Toolkit compliments resources like Walking in Her Moccasins by prefacing action-oriented learning and supporting youth in mobilization. By focusing on active reciprocity, Circle of Aunties brings youth to a place where they can own their responsibilities and begin seeing themselves as co-conspirators with MMIWGT2S families. 


\section{CHAPTER 3 : MOVING BEYOND PERFORMATIVE ALLYSHIP TO ACTIVE CO- CONSPIRATORSHIP WITH MMIWGT2S FAMILIES}

\section{TRUTH, RESPONSIBILITY AND ACTION}

Don't wait around for anyone to proclaim you to be an accomplice; you certainly cannot proclaim yourself. You just are or you are not. The lines of oppression are already drawn. Direct action is really the best and may be the only way to learn what it is to be an accomplice. We're in a fight, so be ready for confrontation and consequence. (Indigenous Action Media 96)

In "Accomplices in the Academy in the Age of Black Lives Matter" scholars Jessica Powell and Amber Kelly define allyship as ideologically positioning white people as those "who assist and people of color as those who need assistance, thereby maintaining oppressive hierarchies" where so-called allies passively claim allegiance to communities through "social media participation or by wearing symbols such as Black Lives Matter t-shirts" failing to engage in any transformative work or "participate in any meaningful action" (45). The authors discuss that there are also some allies who, instead of participating in this highly performative work, feel "immobile" and remain disengaged until they are called upon to do something. Alternatively, coconspiratorship or accomplice work sees white settlers/guests working alongside Indigenous activists in an engaged relationship which is built on trust and the shared desire to dismantle oppressive systems, "When we fight back or forward together becoming complicit in a struggle toward liberation, we are accomplices" (Indigenous Action Media 88). This relationship sees settlers/guests as active co-conspirators who ensure that "Indigenous peoples' voices" are centred as the "breath of our struggle to end suffering"(Flowers 37). There is a balance within this relationship between being effective and owning the labour of the work while also taking direction and being mindful of holding space rather than taking space. The words 'accomplice' and 'co-conspirator' suggest risk - asking those engaged to actively disrupt oppressive systems. 
The Circle of Aunties Toolkit seeks to engage youth in meaningful work which is antioppressive and fosters active co-conspiratorship instead of passive allyship. Its goal is to provide the next generation with the tools to resist violence; keeping themselves safe while also understanding the crisis of Missing and Murdered Indigenous womxn and Girls in Canada and their role in resisting settler colonial violence, in all its forms. The toolkit begins by guiding youth in coming to understand their truth, learning about settler colonial violence in "Canada" and understanding its history. With an understanding of these truths the toolkit turns to action, positioning youth to understand their responsibilities (especially settler-guest youth) once they hold this information and engage in co-conspirator work. Circle of Aunties turns to story, art and community gathering as a way in which to introduce young people to co-conspirator work and violence prevention. This project's contribution to literature lies in its ability to discuss "unknown and 'in-between' spaces of resistance" (Flowers 35) while positioning story, art and community as methods for the next generation to grow and flourish as co-conspirators within these spaces.

Within her novel, Violence Against Indigenous womxn: Literature, Activism, Resistance, Allison Hargreaves highlights the need to be critical of storytelling as a catalyst for social change, expressing that there are "considerable limits involved in uncritically assuming unnecessary correlation between the telling of story and the hopeful outcome of social change"(93). There are two main issues highlighted within the novel which I believe the Circle Of Aunties Toolkit addresses; the passivity of the audience and the power relations involved in both telling and experiencing stories of MMIWGT2S. The passivity of the listener, Hargreaves explains, comes in the belief that "by mere virtue of hearing another story of oppression we have participated in an oppositional act", without doing anything tangible to challenge settler colonialism. An integral element of the Circle of Aunties Toolkit is the stories section which includes videos, podcasts and writing where MMIWGT2S families share who their loved one is. This section asks youth to create a response to the stories they experience, reflecting critically on who the womxn is and how her family celebrates her life. This is followed by youth creating something in honour of those who have lost their lives to violence and organizing a community event where they mobilize the knowledge they have gained. By pairing story with action the toolkit resists passivity and hollow/performative acts of opposition. The second issue which Hargreaves highlights is the relationship between the storyteller and the listener, which can allow 
oppressive power relations to be reinforced, especially when the stories of Indigenous womxn are "solicited and consumed for the education (or perhaps even entertainment) benefit of white interlocutors" (93). Circle of Aunties positions youth as bearing responsibility in resisting settler colonial violence and turns the gaze onto themselves as future co-conspirators. By interrogating each youth's personal truth and placing their own story within the project narrative, the stories of MMIWGT2S are being shared as to mobilize. The project's emphasis on reciprocity sees youth responding to the call of MMIWGT2S families to honour their loved ones and mobilizing their grass-roots work.

Amber Dean is similarly critical of storytelling within her novel, Remembering Vancouver's Disappeared womxn: Settler Colonialism and the Difficulty of Inheritance. Like Hargreaves, Dean is critical of the power relations between the storyteller and the audience as well as the potential erasure of settler colonial oppression and violence. Dean notes that in some storytelling approaches, "the witness, despite good intentions, tends to collapse difference between themselves and those who suffered violence first-hand, erasing complex histories in ways that make it difficult to see how wider social contexts are related to the injustice or violence being witnessed" (4). What is a stake within these narratives, is that the risk of audience members feeling that it could have been them or one of their own loved ones who lost their life to violence (6). The danger here is that, for many settler-guest audiences (specifically white audiences), it could not be them or their loved ones because they do not experience racial violence or intergenerational trauma and their families are not the target of settler colonial erasure. In reflecting on the largely criticized photo exhibit The Forgotten, Dean comments on how "overdetermined the language of bearing witness has become" as it is often used to describe "an empathetic or compassionate response to violence, suffering, or loss that stops short of a reconsideration of how we are ourselves necessarily implicated in the violence of suffering experienced by others" (6). Hargraves and Dean suggest similar solutions for commemorative projects which involve integrating the responsibility of settler audiences. Dean applies Roger Simon's concept of "remembrance as a difficult return" to MMIWG commemoration, an approach which sees the audience as being reflexive about their positionality and privilege:

Memorials that evoke memory as a difficult return challenge us to assess our place in the story in ways quite different from those that primarily deploy memory for strategic 
purposes or invite us to empathetically imagine the womxn might have been anywoman. When memory as a difficult return is evoked, our relation to the losses being memorialized is called into question and potentially refashioned as one substantiated not on our being bystanders to those losses, but on our becoming inheritors, not of the specific or individual losses of womxn we did not know, but instead of what lives on from those losses (140).

\section{In Between Hope and Despair: Pedagogy and the Remembrance of Historical Trauma, Simon} explains that this approach to remembrance collapses the past and the present, attempting to "meet the challenge of what it might mean to live, not in the past but in relation with the past, acknowledging the claim the past has on the present" (4). This is particularly important in regards to settler colonialism as the state continuously attempts to historize its acts of violence and dispossession, even though settler colonialism is an ongoing process and a "structure not an event" (Wolfe 388).

Hargraves speaks to Indigenous storytelling practices as having the ability to evoke responsibility and reflection within the listener - similarly to Dean's reflections on remembrance. Hargraves explains that listening within Indigenous storytelling, "comes with responsibilities of interpretation and understanding that go beyond liberal forms of recognition toward a witnessing" (121). This critical positioning of oneself pushes the storytelling experience towards an anti-oppressive project as it demands the audience to understand larger systemic oppression and recognize their own responsibility in addressing settler colonial violence. Both approaches offered by the authors provide opportunities for action versus passive emotional responses. Circle of Aunties responds to the call of these authors by contextualizing settler colonialism for youth and evoking memory as a difficult return, where youth are introduced to stories of MMIWGT2S and asked to see themselves in "relation to the losses being memorialized", moving as Simon writes from "being bystanders to those losses" to inheritors, "of what lives on from those losses". This means inheriting their responsibility in resisting violence and, for settler-guest specifically, it means inheriting their role in resisting structural genocide. 


\section{EMPLOYING COMMEMORATIVE STORYTELLING AND RESISTING THE LEGACY OF VIOLENT SETTLER COLONIAL RHETORIC}

Dean and Hargreaves critically call storytelling into conversation and critique its tendency to encourage passivity and feelings of closeness to the stories of MMIWGT2S instead of interrogating oppressive settler colonial systems. While the Circle of Aunties Toolkit is critical of these limitations and seeks to both resist passivity and interrogate systemic oppression, it also sees the value in presenting the stories of MMIWGT2S as multidimensional womxn and encouraging youth to form a connection to their stories. The legacy of dehumanizing rhetoric in "Canada" is integral in maintaining its legitimacy as a settler colonial state and normalizing violence against Indigenous womxn; thus, the importance of countering this narrative with commemorative storytelling should not be dismissed, but critically explored. In "The Duty of the Canadian Media in Relation to the Violence against Native Women" Isela Perez-Torres writes that the Canadian media has the potential to make a difference in regards to MMIWGT2S, as they "can work to dignify the victims and their families and contribute to the correction of the injustices and inequalities from which the victims are suffering. They can put a brake on and eliminate political decisions and actions that do not guarantee the safety of Indigenous women and that have violated their rights". Perez-Torres stresses that reporters must embark on a paradigm shift, they must "distance themselves from patriarchal and racist ideologies, from the discourse of the elite and their economic interests" (Pérez-Torres 170 - 171). The Circle of Aunties Toolkit looks to the next generation of storytellers, reporters, policymakers and public servants. Our goal is to inspire this 'distancing' in youth by providing an alternative narrative which is deeply personal and action orientated.

The complexities and difficulties of resisting violent settler colonial ideologies cannot be underestimated. Colonial rhetoric in news media has been used strategically by the government of "Canada" to shape the values of settler communities and justify its treatment of Indigenous Peoples for over a century. As Janie Jamieson, Spokesperson of the Six Nations of Grand River expressed at a rally in 2007, 'It's the job of the Canadian government's' mainstream media to help the RCMP and OPP to use whatever means necessary to conjure up early European images of uncivilized crazed "lawless" savages (...) Canada then criminalizes our right to stand up and protect our very existence"(qtd. in Schertow, “Aug 21 Speech”). In his work, "Historical Representations of Aboriginal people in the Canadian News Media", Robert Harding draws from 
news texts ranging from the 1860 s to the 1990s, exploring the long and consistent history of misrepresentation and colonial violence within the Canadian media. The wide temporal breadth of Harding's research demonstrates the importance in understanding not only how colonial values first began to disseminate amongst the "Canadian" public, but the need to also recognize the consistent continuation of these colonial values. While the more overtly racist portrayals of Indigenous Peoples in the media may have largely disappeared, Harding explains that racism in the media exits through "ethnocentrism" (the emphasis of equal opportunity and cultural pluralism), the denial of current racist practices and the neglect to consider socio-political contexts when reporting on the dire situations of poverty and addiction which some Indigenous Peoples live with (2). These more subtle examples of colonial violence within news media are extremely effective and as Harding states, these discourses "help sustain, and are themselves reinforced by, official state policy regarding aboriginal people as well as Canadian society's general amnesia about the country's colonial history" (2). The dehumanizing and often victimblaming rhetoric shapes the public's opinion around whose life is worth mourning and who is merely expected to die due to their 'poor lifestyle'. Isela Pérez-Torres explains public discourse to be a breeding ground for discrimination, stating that "both media and journalists are an important link in the preservation of this discriminatory ideology." (Pérez 162). In her writing on the Murder of Pamela George, a Salteaux woman from Regina, Sherene Razack explains the historical presence of violence against Indigenous womxn in Canada being a colonial violence which enabled settlers to not only take Indigenous land but to believe they were entitled to it (Razack 97). Newspaper reports from the 19th century played a major role in encouraging this violence, framing Indigenous womxn as 'promiscuous' and 'sexually loose', perpetuating a narrative which suggested that if Indigenous womxn faced violence they "simply got what they deserved" (Razack 99).

Jiwani and Young outline the major differences in how the media reports on violence against racialized womxn, often "invoking and re-inscribing popular stereotypes of these womxn as being hypersexual, thereby minimizing the reality of the violence done to their bodies" (Jiwani and Young 901). This narrative which has been present within the Canadian media for over a hundred years has majorly influenced settler attitudes towards Indigenous womxn and has worked to justify the colonial state's attempts of the erasure of Indigenous womxn. The images which are chosen to represent missing and murdered Indigenous womxn within the media also 
send a powerful message which works to further criminalize and devalue their bodies. Jiwani and Young discuss this in regards to missing Indigenous womxn in Vancouver's Downtown Eastside, describing a poster which was circulated by police and the press featuring "mug shots of the missing womxn - although photos of some of the womxn were not available and were therefore left blank. Nonetheless, these close-cropped shots not only reinforced the womxn's association with criminality (England 2004), but also highlighted the Aboriginal heritage of many of the missing womxn" (898). As Gail Mason discusses in her work, The Spectacle of Violence: Homophobia, Gender and Knowledge, in viewing violence against bodies not only is power exerted but the way in which we recognize those bodies shifts:

I pick up the idea, shared by both feminists and Foucault, that the nexus between violence and power is an instrumental one; that is, violence is an instrument of power. I suggest that we might think of instrumentality as a question of knowledge, of the capacity of violence to shape the ways that we see, and thereby come to know, certain things. In this way, the act of violence itself is a spectacle. This is not so much because violence is something that we observe, but, more, because violence is a mechanism through which we distinguish and observe other things. In other words, violence is more than a practice that acts upon individual subjects to inflict harm and injury. It is, metaphorically speaking, also a way of looking at these subjects (11).

In her essay "The Unmournable Body of Cindy Gladue", Caroline Doenmez similarly explores how violence changes the way in which we see individuals and understand their worth. Doenmez explains that the Canadian State is not only apathetic but waiting and expecting Indigenous womxn and girls to disappear as they are considered to be "always on the brink of death for a state that requires their disappearance to legitimize its ongoing acts of dispossession and the evasion of their own history - a history that structures the very problem that they supposedly become" (Doenmez 114). In Precarious Life: The Powers Of Mourning And Violence, Judith Butler, an American philosopher and gender theorist, explores this tendency of the public to react with apathy when violence enacted upon certain groups of people. Butler wrote this monumental piece in the wake of 9/11 exploring first-world privilege, the treatment of Palestinians and the state of the Guantánamo prisoners. She introduces her notion of "ungrievable-unreal” lives, 
which argues that if violence is done against those who are "unreal", then it "fails to injure or negate those lives since those lives are already negated", meaning that "They cannot be mourned because they are always already lost, or, rather, never "were"' (Butler 30). The devaluing of racialized bodies renders their erasure invisible in the eyes of the public:

There will be no public act of grieving (...) If there is a 'discourse', it is a silent and melancholic one in which there have been no lives, and no losses; there has been no common bodily condition, no vulnerability that serves as the basis for an apprehension of our commonality; and there has been no sundering of that commonality (. . .) In the silence of the newspaper, there was no event, no loss, and this failure of recognition is mandated through and identification with those who identify with the perpetrators of that violence. (Butler 36)

By including deeply personal and strength-based storytelling, the Circle of Aunties Toolkit calls for the visibility of MMIWGT2S as multidimensional, real and grievable. Each piece within the toolkit exists for the sole purpose of honouring that womxn and telling her story how her loved ones want it to be told. These stories exclude details of how these womxn died, resisting the expected violent details of their deaths and inviting honouring instead of sensationalization. Reflecting on Marilyn Dumont's poem "Helen Betty Osborne"(a young Cree woman from Norway House reserve who was kidnapped and murdered in Alberta, 1971), Hargreaves discusses how excluding details of violence can be productive in resisting dehumanizing rhetoric. Hargraves writes about Dumont's decision to exclude the details of Helen Betty Osborne's death, stating that "Rather than putting story forward as a transparent means of promoting awareness and social change, the poem complicates how public knowledge about violence is produced" (93). By refusing to share these details, Circle of Aunties works to resist Hargreaves' critique of commemorative projects. This is not a space for entertainment or the sensationalization of violence but a space of honouring, truth and resistance.

Powell and Kelly call for white accomplices to resist sharing stories of their emotional "pleas for justice on social media and in other spaces" as to avoid the risk of "dominating the conversation" and becoming "inactive due to feelings of guilt". Instead, the authors call for coconspirators to utilize their privilege as to "access platforms where they can speak out against 
white supremacy while simultaneously engaging in moments of quiet to hold space for people of color to occupy" (60). By supporting youth in placing themselves within the narrative of settler colonial violence, Circle of Aunties exists as a tool for transformation and understanding one's role in ending violence against Indigenous Womxn, Girls, Trans and Two Spirit Peoples. With the empowerment of families at its core, this commemorative and anticolonial work introduces youth to co-conspiratorship and calls them to action. 


\section{CHAPTER 4: CIRCLE OF AUNTIES: HONOURING MMIWGT2S FAMILIES}

As awareness about missing and murdered women grows and many people speak up, in doing so we must be attentive not to silence the voices of the families of these women. (Flowers 37)

At our most recent gathering, we began thinking through how to name our project. The idea of "Aunties" surfaced as a symbol for the womxn in our lives who we care for like family - even if we are not related by blood. It embodies respect, love and connection. The families began comparing the meaning of Auntie in their languages - discussing that in Anishinaabemowin and Oneida the word for Auntie is similar or the same as words for other family members like mother and grandmother. We began to explore this idea in relation to what we want our toolkit to embody and how we want it to engage youth. This understanding of Auntie helps youth to reconsider their positionality and asks - what if we understood all womxn to be our Aunties? What if we felt responsibility for every womxn as if she were our Auntie and understood her connection to others as someone who is valued and loved? It also calls womxn to action, asking to consider the responsibilities as Aunties to care for the next generation - providing support, guidance and protection. The project was named based on this idea of internalizing the responsibility to respect and care for one another. Circle of Aunties prefaces truth and responsibility, asking for co-conspiratorship which is based on authentic and trusted relationships. This centres MMIWGT2S families as Aunties; as leaders to take direction from in the resistance of settler colonial violence - honouring their lived experience and knowledge.

In the wake of the National Inquiry, it is especially important to centre the voices of MMIWGT2S families. As public dialogue around MMIWGT2S increases and "in the rise of public and academic discourse about missing and murdered Indigenous women that was originally led by the voices of the families of missing and murdered women, as well as Indigenous activists in the communities" (Flowers 37) families cannot be silenced. Leanne Betasamosake Simpson, an Michi Saagiig Nishnaabeg scholar, wrote "Not Murdered and Missing: Rebelling against Colonial Gender Violence” in 2014 - one year before the pre-inquiry process. Simpson reflects on the then impending National Inquiry into Missing and Murdered Indigenous Women and Girls, stressing that she is doubtful that it will render the results which 
Indigenous communities need or "address the root causes of gender violence" (121). Since its beginning families and advocates have been speaking out against the inquiry, holding it accountable publicly. Throughout the inquiry process headlines read, “'They're not there to help': MMIWG family members say counselling support lacking" (Coulter), "Manitoba Chief Slams MMIWG Inquiry Process" ("Manitoba Grand Chief”), "Director's resignation from MMIWG inquiry a sign of dysfunction, advocates say" (MacLeans). Perhaps one of the most powerful and telling headlines reads, "More than 100 MMIWG cases listed since Trudeau took office" (Barrera $\mathrm{CBC}$ ), speaking to the fact that regardless of the inquiry - violence against Indigenous Womxn and Girls persists. In the wake of this oppressive and tumultuous inquiry - it is vital that families of Murdered Indigenous Womxn, Girls, Trans and Two-Spirit People are centred in designing solutions for resisting settler colonial violence. As Simpson states, "The perpetrators of colonial gender violence cannot be in charge of coming up with a strategy to end it because they are beneficiaries of it" (121). Circle of Aunties calls for a paradigm shift in how gendered settler colonial violence is interrogated and whose knowledge is leading that work. It centres the families of Missing and Murdered Indigenous Womxn, Girls, Trans and Two Spirit People as experts and calls forward co-conspirators to support their work. As Simpson stresses, "We simply can no longer rely on or expect the state, the largest perpetrator of gender violence, to do this for us (...) \#ItEndsHere" (123). 


\section{CONCLUSION}

There isn't one right way to move to accomplice action against white supremacy. We acknowledge that this may look different depending on your work environment and the communities you serve. It's messy, hard, and we may not always get it right, however the necessity to take action is urgent. We realize there are risks inherent in the work to become involved on the front lines of social and cultural change. The academic as accomplice perspective asks a lot of each of us. Yet, to build a more liberatory world for us all, our view is that we can do no less. (Powell and Kelly 61)

In 1937, my grandfather Deiter Heidenheim and his parents fled Germany for Amsterdam with the hope that the Nazis would not invade. It was in Holland that they met the Benders, a Dutch family who were Jewish allies and sought to support my great-grandparents. In 1940 the Nazis invaded Holland and it was Johan Benders who intervened and saved my grandfather's life. Deiter wrote in his journals, "When the Nazis invaded on May 14th, we listened to the announcement over the radio and wept when they played the Dutch National anthem for the last time. It wasn't long afterwards that Mr. Benders came to the back door to check up on us and to find out about our plans (...) Mr. Benders drew a map for me to the harbour of Ymuiden (on the coast). The hope was that there would be a good chance to find a small fishing boat which might be able to take me to England". My grandfather escaped but his parents were sent to the Auschwitz concentration camp. Johan Benders was captured by the Nazis and committed suicide as to protect the information which he held. I recently went to Holland to meet the descendants of Johan Benders who have done an extensive amount of research and writing - producing a book about his life. I found it difficult to comprehend the magnitude of this trip, to speak with the Benders and grasp that the sacrifice of their father is the reason my family exists. It was at their book launch that I began to understand:

As we waited for the event to start, Ellen began speaking to me. "It's amazing" I said, "It was so kind of your family to help my family.... I wouldn't exist if they hadn't". She smiled at me, shaking her head "It wasn't kindness" she corrected, "It was love. To face fascism and to do something because you love, not just because you care or out of 
kindness...is different". It suddenly dawned on me - this love was so deep it seeped down through generations. It was embedded in the bones of the Benders children. It moved two sisters to find a family a world away, research and commemorate. Love means sacrifice and risk - its offerings are unconditional. It transcends the limitations of time and space it prevails. (Heidenheim 17)

Powell and Kelly assert that risk is what sets allyship and accomplice work apart, where one engages in the act of destabilizing "white supremacy in ourselves, families, schools, communities, and within the judicial system"(43). Instead of the benevolent and performative work of allyship, co-conspiratorship sees accomplices becoming vulnerable: "The risks of an ally who provides support or solidarity (usually on a temporary basis) in a fight are much different than that of an accomplice. When we fight back or forward together becoming complicit in a struggle toward liberation, we are accomplices" (Indigenous Action Media 88). As I review our question, "can we work together to create a transformative project and centre the lived experience of the families?" and consider this notion of risk - I think to the most recent Shades of Our Sisters exhibit we held at St. James Cathedral. The exhibit took place in the wake of Riya Rajkumar's death. Riya was murdered by her father on February 14th, on her 11th birthday. February 14th is a day in which MMIWGT2S activists gather across the nation holding marches, ceremony and demonstrations. The families gathered for our second working meeting on February 14th and participated in local feasts. We were together when we all received the amber alert to our phones. The alert caused a backlash from the public with complaints being made about its intrusiveness - a telling moment for how we address, or rather prefer not to address, violence in "Canada". The amber alert was felt by our group with a devastating weight - I remember feeling sick to my stomach and seeing a look in the eyes of many of the womxn that this was all too familiar to them. It put a sort of urgency on our work. When we gathered the following evening for Shades of Our Sisters, an evening dedicated to MMIWGT2S and honouring their loved ones, this question seemed to be called forward - and it was the loved ones of Missing and Murdered Indigenous Women and Girls who answered. The families all called for us to speak of Riya, to hold space for her life and to pray for her family. We started the evening with a moment of silence; a group of eighty community members stood in total silence, grief hung in the air. The family members then, one by one, began to speak - each one honouring 
Riya and holding space for her. Centring HER. In that moment this question entered the room and was answered.

The community rallied that evening for Riya and for MMIWGT2S. Representatives from the Muslim faith, Jewish faith and Anglican faith came and offered prayer. When the Imam began to speak she was overcome with emotion and looked to the families - her prayer rang through the massive cathedral. These communities came, held space and honoured - in solidarity. With MMIWGT2S families centered the community gathered and listened. They offered families tobacco, shared time, embraced, cried. It is not my intent to simplify the resistance of settler colonialism and structural genocide, nor am I trying to suggest that embarking on coconspiratorship is simple. Interrogating structural violences is integral - work cannot exist as anti-oppressive if it fails to disrupt the settler colonial state. Embodying the call to accomplice work is complex, messy and often paralyzing. But in this moment the power of community seemed to fill the room and answer these challenges with an overwhelming force - it was honest, it was selfless, it was brave, it was grief, it was anger, it was hope. It was showing up and it was holding space. It was not simply closing gaps but coming to understand and question those gaps - critically, in order to dismantle them. It centred survivors and loved ones, following their wisdom and strength. It was vulnerable, it was strong, it was love.

I recently gave a presentation for one of Dr. Koleszar-Green's social work classes. I spoke about my experiences working towards co-conspiratorship and outlined the work of Indigenous scholars and activists who have written about how to properly engage in antioppressive work. After the presentation one student asked me, "What is the most important element in doing co-conspirator work? Is there one thing that is absolutely vital?". At the time the answer came to me so quickly and, as I write, I can now appreciate why. Relationship, I said, is the most important thing; because if you have relationship then respect, reciprocity and true co-conspiratorship work will follow. This is something the families have ingrained in me and has guided our work over the last four years. Once you have relationship you will feel the urgency to unsettle yourself, to understand critically oppressive systems and to tear them down and to take active risks. You will interrogate your privilege because your privilege is, as Rachel Flowers explains "the basis for injustice and oppression of Indigenous peoples, the privilege of the settler is predicated on the unfreedom of the colonized" (34). Temporally your work will not waver because you are accountable to those you are working with as you have a relationship which has 
fostered trust and respect. They are your co-conspirators and your accomplices in the resistance of oppression. In "Accomplices Not Allies: Abolishing the Ally Industrial Complex", Indigenous Action Media writes, "Accomplices are realized through mutual respect and build trust. They don't just have our backs; they are at our side, or in their own spaces confronting and unsettling colonialism. As accomplices, we are compelled to become accountable and responsible to each other; that is the nature of trust" (96). 


\section{WORKS CITED}

Aboriginal Peoples Congress. Walking In Her Moccasins.

Absolon, K., \& Willett, C. Putting Ourselves Forward: Location in Aboriginal Research. In L. Brown \& S. Strega (Eds.), Research as Resistance: Critical, Indigenous and Antioppressive Approaches(pp. 97-126). Canadian Scholars’ Press, (2005).

Barrera, Jorge. "More than 100 MMIWG Cases Listed since Trudeau Took Office, Group Says | CBC News." CBCnews, CBC/Radio Canada, 10 Oct. 2018, www.cbc.ca/news /indigenous/mmiwg-list-cases-1.4856500.

Brown, Leslie A., and Susan Strega. Research as Resistance: Revisiting Critical, Indigenous, and Anti-Oppressive Approaches. Canadian Scholars' Press, 2015.

Butler, Judith. Precarious life: The Powers of Mourning and Violence. Verso, 2006.

Cauchie, NCCAH Communications Officer Lesa. "National Collaborating Centre for Aboriginal Health $>$ Home $>$ PUBLICATIONS > Publication Search." NCCAH, www.ccnsa-nccah.ca/495/Indigenous_Approaches_to_Program_Evaluation.nccah?id=1 25.

Community Resource Guide: What Can I Do to Help the Families of Missing and Murdered Aboriginal Women and Girls? The Native Women's Association Canada, 2010.

Coulter, Christine. “'They're Not There to Help': MMIWG Family Members Say Counselling Support Lacking | CBC News.” CBCnews, CBC/Radio Canada, 25 Nov. 2018, www.cbc.ca/news/canada/british-columbia/they-re-not-there-to-help-mmiwg-familymembers-say-counselling-support-lacking-1.4919281.

Dean, Amber R. Remembering Vancouver's Disappeared Women: Settler Colonialism and the Difficulty of Inheritance. Toronto University Press, 2015.

Doenmez, Caroline Fidan Tyler. "The Unmournable Body of Cindy Gladue, On Corporeal Integrity and Grievability." Forever Loved, Exposing the Hidden Crisis of Missing and Murdered Indigenous Women and Girls in Canada, Demeter Press, 2016, pp. 111-127.

Flowers, Rachel. “Refusal to Forgive: Indigenous Women's Love and Rage.” Decolonization: Indigeneity, Education \& Society, vol. 4, no. 2, 2015, pp. 32-49. 
Foucault, M., \& Ewald, F. (2008). Society must be defended: Lectures at the Collége de France, 1975-76. London: Penguin.

Greenhalgh, T., Jackson, C. , Shaw, S. and Janamian, T. (2016), Achieving Research Impact Through Co-creation in Community-Based Health Services: Literature Review and Case Study. The Milbank Quarterly, 94: 392-429.

Fabricant, Robert, et al. Collective Action Toolkit. 2012.

Harding, Robert. "Historical Representations of Aboriginal People in the Canadian News Media." Discourse \& Society, vol. 17, no. 2, 2006, pp. 205-235.

Hargreaves, Allison. "Finding Dawn and Missing Women in Canada: Story-Based Methods in Antiviolence Research and Remembrance." Studies in American Indian Literatures, vol. 27 , no. 3, 2015, pp. 82-111.

Hargreaves, Allison. Violence Against Indigenous Women: Literature, Activism, Resistance. Wilfrid Laurier University Press, 2017.

Heidenheim, Laura. “Journal Entries.” 2019.

Indigenous Action Media. "Accomplices Not Allies: Abolishing the Ally Industrial Complex." Taking Sides: Revolutionary Solidarity and the Poverty of Liberalism, AK Press, 2015, pp. 86-96.

Jiwani, Yasmin, and Mary L. Young. "Missing and Murdered Women: Reproducing Marginality in News Discourse." Canadian Journal of Communication, vol. 31, no. 4, 2006, pp. 895.

Kimpson, Sally. Stepping off the Road: A Researcher's story of challenging method/changing methodology. In L. Brown \& S. Strega (Eds.), Research as Resistance: Critical, Indigenous and Anti-oppressive Approaches(pp. 97-126). Canadian Scholars’ Press, (2005).

Koleszar-Green, Ruth. "What Is a Guest? What Is a Settler?” Cultural and Pedagogical Inquiry, vol. 10, no. 2, 2018, pp. 166-177., doi:10.18733/cpi29452. 
Kovach, Margaret. "Emerging from the Margins: Indigenous Methodologies." Research as Resistance: Revisiting Critical, Indigenous, and Anti-Oppressive Approaches, Canadian Scholars Press, 2015.

Lampen, Claire. "What Does It Mean to Identify as a 'Womyn?'." The Daily Dot, The Daily Dot, 11 Apr. 2018, www.dailydot.com/irl/womyn/.

“LAND ACKNOWLEDGEMENT.” Ryerson School of Journalism, Ryerson School of Journalism, trc.journalism.ryerson.ca/land-acknowledgement/.

Lavallée, Lynn F. "Practical Application of an Indigenous Research Framework and Two Qualitative Indigenous Research Methods: Sharing Circles and Anishnaabe SymbolBased Reflection." International Journal of Qualitative Methods, vol. 8, no. 1, 2009, pp. 21-40.

Lavell-Harvard, Memee, and Jennifer Brant. "Introduction, Forever Loved." Forever Loved, Exposing the Hidden Crisis of Missing and Murdered Indigenous Women and Girls in Canada, Demeter Press, 2016, pp. 1-13.

Macdonald, Nancy. 'It Could Have Been Me' Thirteen Remarkable Women Share Their Own Stories. Macleans, 2015, site.macleans.ca/longform/almost-missing/index.html.

MacLeans, Cameron. "Director's Resignation from MMIWG Inquiry a Sign of Dysfunction, Advocates Say | CBC News." CBCnews, CBC/Radio Canada, 12 Jan. 2018, www.cbc.ca/news/canada/manitoba/mmiwg-inquiry-executive-director-resignationreaction-1.4484871.

"Manitoba Grand Chief Slams MMIWG Inquiry Process." CityNews, 10 Dec. 2018, www.citynews1130.com/video/2018/12/10/manitoba-grand-chief-slams-mmiwg-inquiryprocess/.

Martin, Bella, and Bruce M. Hanington. Universal Methods of Design: 100 Ways to Research Complex Problems, Develop Innovative Ideas, and Design Effective Solutions. Rockport Publishers, 2012. 
Mason, Gail. The Spectacle of Violence: Homophobia, Gender, and Knowledge. Routledge, 2002.

Nabigon, Herbert, et al. “"The Learning Circle as a Research Method: The Trickster and Windigo

in Research.'” Applying Circles in Aboriginal Social Work Practice, vol. 2, 1999, pp. $119-143$.

Ontario Native Women's Association. Fact Sheet: Missing and Murdered Indigenous Women and Girls. 24 Nov. 2017, www.onwa.ca/upload/documents/fact-sheets/fact-sheet-mmiwg -v4--2017-11-24--int.pdf.

Palmater, Pamela. "Shining Light on the Dark Places: Addressing Police Racism and Sexualized Violence Against Indigenous Women and Girls in the National Inquiry." Canadian Journal of Women and the Law, vol. 28, no. 2, 2016, pp. 253-284.

Pérez-Torres, Isela. "The Duty of the Canadian Media in Relation to the Violence against Native Women: Lessons Drawn from the Case of Ciudad Juárez." Forever loved: exposing the hidden crisis of missing and murdered indigenous women and girls in Canada, Demeter Press, 2016.

Powell, Jessica, and Amber Kelly. "Accomplices in the Academy in the Age of Black Lives Matter." Journal of Critical Thought and Praxis, vol. 6, no. 2, 2017.

Razack, Sherene H. "Gendered Racial Violence and Spatialized Justice: The Murder of Pamela George," Canadian Journal of Law and Society vol. 15, no. 2 (2000): p. 91-130.

Robertson, Nyk. "The Power and Subjection of Liminality and Borderlands of Non-Binary Folx." Gender Forum: An Internet Journal of Gender Studies, vol. 69, no. 69, 2018, pp. $45-76$.

Schertow, John Ahni. “Aug 21 Speech Delivered To Law Society Of Upper Canada." Intercontinental Cry, 21 Aug. 2007. 
Simon, Roger I., et al. Between Hope and Despair: Pedagogy and the Remembrance of Historical Trauma. Rowman \& Littlefield Publishers, 2000.

Simpson, Audra. "The State is a Man: Theresa Spence, Loretta Saunders and the Gender of Settler Sovereignty." Theory \& Event, vol. 19, no. 4, 2016, pp. N_A.

Simpson, Leanne Betasamosake. "Not Murdered and Missing: Rebelling against Colonial Gender Violence.” Taking Sides: Revolutionary Solidarity and the Poverty of Liberalism, AK Press, 2015, pp. 115-123.

Smith, Hazel, and R. T. Dean. Practice-Led Research, Research-Led Practice in the Creative Arts. Edinburgh University Press, 2009.

Suzack, Cheryl. "Indigenous Feminisms in Canada." NORA - Nordic Journal of Feminist and Gender Research, vol. 23, no. 4, 2015, pp. 261-274.

Tomiak, Julie. "Unsettling Ottawa: Settler Colonialism, Indigenous Resistance, and the Politics of Scale." Canadian Journal of Urban Research, vol. 25, no. 1, 2016, pp. 8-21.

Tuck, Eve, and Wayne K Yang. "Decolonizing is not a Metaphor.” Decolonization: Indigeneity, Education \& Society, vol. 1, no. 1, pp. 1-40.

Wilson, Shawn. Research is Ceremony: Indigenous Research Methods. Fernwood Pub, 2008.

Wolfe, P. (2006). Settler colonialism and the elimination of the native. Journal of Genocide Research, 8(4), 387-409. 